\title{
The Differential Expression of Low-Threshold Sustained Potassium Current Contributes to the Distinct Firing Patterns in Embryonic Central Vestibular Neurons
}

\author{
Georgi Gamkrelidze, Christian Giaume, and Kenna D. Peusner \\ Department of Anatomy and Cell Biology, and Neuroscience Program, George Washington University Medical Center, \\ Washington, DC 20037
}

\begin{abstract}
The principal cells of the chick tangential nucleus are secondorder sensory neurons that participate in the three-neuron vestibulo-ocular and vestibulocollic reflexes. In postnatal animals, second-order vestibular neurons fire repetitively on depolarization. Previous studies have shown that, although this is an important feature for normal reflex function, it is only acquired gradually during embryonic development. Whereas at 13 embryonic days (E13) the principal cells accommodate after firing a single spike, at $\mathrm{E} 16$ a few principal cells repetitively can fire multiple action potentials on depolarization. Finally, in the hatchling, the vast majority of principal cells is capable of nonaccommodating firing on depolarization. As a first step in understanding the mechanisms underlying developmental change in excitability of these second-order vestibular neurons, we analyzed the outward potassium currents and their role in accommodation, using brainstem slices at E16. The principal
\end{abstract}

cells exhibited transient and sustained potassium currents, with both of these containing calcium-dependent components. Further, both high- and low-threshold sustained potassium currents have been distinguished. The low-threshold dendrotoxinsensitive sustained potassium current $\left(l_{\mathrm{DS}}\right)$ is associated with principal cells that accommodate and is not expressed in those that fire repetitively. Finally, blocking of $I_{\mathrm{DS}}$ transforms accommodating cells into neurons capable of firing trains of action potentials on depolarization. These findings indicate that suppression of $I_{\mathrm{DS}}$ during development is sufficient to transform accommodating principal cells into nonaccommodating firing neurons and suggests that developmental regulation of this current is necessary for the establishment of normal vestibular function.

Key words: dendrotoxin; potassium current; central vestibular neurons; chick embryo; excitability; firing pattern
The three-neuron vestibulo-ocular and vestibulocollic reflexes represent the most direct vestibular pathways involved in the stabilization of gaze during head and body movements (Kelly, 1991). The chick tangential nucleus, located in the lateral part of medulla oblongata, participates in the central segment of this circuit (Cox and Peusner, 1990). The bodies of the major cell population of the tangential nucleus, the principal cells $(80 \%)$, receive large calyx-like terminals from the largest-diameter primary vestibular fibers, the colossal fibers (see Fig. 1A) (Peusner and Morest, 1977). The axons of the principal cells innervate motor neurons situated at cervical levels of the spinal cord (Gross and Oppenheim, 1985; Cox and Peusner, 1990) and also in brainstem oculomotor nuclei, including the oculomotor (Wold, 1978), trochlear (Labandeira-Garcia et al., 1989), and abducens nuclei (Cox and Peusner, 1990). Thus, these second-order vestibular neurons relay signals in both the vestibulo-ocular and the vestibulocollic reflex pathways.

From studies of brainstem slices of postnatal chicks, it appears that second-order vestibular neurons are capable of sustained, nonaccommodating firing of trains of action potentials on depolar-

Received Aug. 26, 1997; revised Nov. 17, 1997; accepted Nov. 20, 1997.

This work has been supported by the National Institute on Deafness and Other Communication Disorders, National Institutes of Health, Grant RO1 DC00970.

Correspondence should be addressed to Dr. Kenna D. Peusner, Department of Anatomy and Cell Biology, and Neuroscience Program, George Washington University Medical Center, 2300 I Street, NW, Washington, DC 20037.

Dr. Giaume's present address: Institut National de la Santé et de la Recherche Médicale (INSERM) U114, College de France, 11 Place Marcelin Berthelot, 75231 Paris Cedex 05, France.

Copyright (C) 1998 Society for Neuroscience $\quad 0270-6474 / 98 / 181449-16 \$ 05.00 / 0$ ization (du Lac and Lisberger, 1995a,b; Peusner and Giaume, 1997). During vestibulo-ocular and vestibulocollic behavior these vestibular neurons appear to encode information on firing rate (Chubb et al., 1984; Lisberger et al., 1994; Ris et al., 1995; Boyle et al., 1996; Phillips et al., 1996). Apparently, the ability of nonaccommodating firing of action potentials by second-order vestibular neurons is essential for the normal function of these reflexes (du Lac and Lisberger, 1995a). Previously, it has been shown (Peusner and Giaume, 1997) that the principal cells gradually acquire the ability of nonaccommodating firing of action potentials during chick embryonic development. At embryonic day 13 (E13) the principal cells accommodate after firing a single action potential, whereas E15-E16 appears to represent a turning point when only a few principal cells exist that can fire multiple action potentials. Finally, in the hatchling, the vast majority of principal cells fires repetitively on depolarization (Peusner and Giaume, 1997).

In various nuclei of the central auditory pathway, it has been found that potassium currents play an essential role in determining whether these neurons are capable of firing trains of action potentials or of accommodating (Manis and Marx, 1991; Banks and Smith, 1992; Forsythe and Barnes-Davies, 1993; Brew and Forsythe, 1995). As a first step in understanding the mechanisms underlying developmental changes in the excitability of secondorder vestibular neurons, we have analyzed outward potassium currents and their role in accommodation of the principal cells at E16. We have found that the principal cells possess transient and sustained potassium currents and that both of these currents exhibit calcium-dependent components. Further, both high- and low-threshold sustained potassium currents are present in these 
cells. The low-threshold, dendrotoxin-sensitive sustained potassium current $\left(I_{\mathrm{DS}}\right)$ is associated with accommodating principal cells and is not expressed in those principal cells that fire multiple spikes on depolarization. Finally, block of $I_{\mathrm{DS}}$ transforms neurons firing a single spike into those capable of nonaccommodating firing of action potentials.

\section{MATERIALS AND METHODS}

Preparation and solutions. All observations were made on 16-d-old white Leghorn chick embryos (Gallus gallus) obtained from Truslow farms (Chestertown, MD) as eggs that were incubated in the laboratory until the desired age. The age of the embryos was determined by reference to the staging criteria of Hamburger and Hamilton (1951).

The basic techniques for the preparation of brain slices of the vestibular nuclei were followed as already described (Peusner and Giaume, 1989, 1994). The protocols applied to animals were approved by the Institutional Animal Care and Use Committee of the George Washington University. Embryos were cooled to room temperature, removed from the egg, and decapitated. The medulla was sectioned transversely at $300 \mu \mathrm{m}$ thickness in chilled $\left(5^{\circ} \mathrm{C}\right)$ artificial CSF (ACSF) with a microslicer (DSK, model 3000, Ted Pella, Redding, CA). ACSF solution (in $\mathrm{mm}$ ) contained $124 \mathrm{NaCl}, 5 \mathrm{KCl}, 2.2 \mathrm{NaH}_{2} \mathrm{PO}_{4}, 2 \mathrm{MgSO}_{4}, 2 \mathrm{CaCl}_{2}, 26$ $\mathrm{NaHCO}_{3}$, and 10 glucose. The $\mathrm{pH}$ of this solution was 7.3-7.4 after saturation with $95 \% \mathrm{O}_{2} / 5 \% \mathrm{CO}_{2}$ at $30-31^{\circ} \mathrm{C}$.

Slice perfusion and microscopy. Slices containing the tangential nucleus were submerged in a small glass-bottom recording chamber (volume, 250 $\mu \mathrm{l}$; Warner Instrument, Hamden, CT) and held in place by nylon threads glued to a U-shaped, flattened platinum wire. The slices were perfused with heated $\operatorname{ACSF}\left(30-31^{\circ} \mathrm{C}\right)$ at a rate $1-2 \mathrm{ml} / \mathrm{min}$. After the slices were incubated in the chamber, they were allowed to equilibrate for at least 1 $\mathrm{hr}$ before recording was started. The slices were viewed with the aid of a fixed-stage upright microscope (Axioskop FS, Zeiss Instruments, Jena, Germany) equipped with differential interference contrast (DIC) Nomarski optics and a $40 \times$ water immersion lens ( 0.75 numerical aperture) with a $1.9 \mathrm{~mm}$ working distance (Zeiss Instruments). Visualization of the recorded neuron and pipette movement was achieved by using an infrared light source (filter $l_{\max }=770 \mathrm{~nm}$ ), which was detected by an infrared-sensitive camera (Vidicon C2400-01; Hamamatsu, Hamamatsu City, Japan) and observed on a monitor (Sony, Tokyo, Japan). The microscope image was magnified further by a $4 \times$ lens placed between the microscope and the camera. Image contrast and shading were adjusted with a camera controller (Hamamatsu C2400), and prints were made on a videographic printer (Sony UP-890MD).

In experiments using $2 \mathrm{mM} \mathrm{CoCl} 2, \mathrm{CaCl}_{2}$ was removed to assist in blocking the calcium currents, and $\mathrm{NaH}_{2} \mathrm{PO}_{4}$ was removed to prevent its precipitation with cobalt. In experiments using $300 \mu \mathrm{M} \mathrm{CdCl} 2$, both $\mathrm{NaH}_{2} \mathrm{PO}_{4}$ and $\mathrm{MgSO}_{4}$ were removed to avoid their precipitation with cadmium. Finally, in solutions containing $0 \mathrm{~mm} \mathrm{Ca}, 5 \mathrm{mM} \mathrm{MgCl}_{2}$ was added. When $>2 \mathrm{~mm}$ changes were made in the total concentration of the solution, $\mathrm{NaCl}$ was adjusted in equinormal amounts. All of the drugs were prepared daily by dissolving them in ACSF and then adding them to the bath to achieve their final concentrations. Tetraethylammonium chloride (TEA; Sigma, St. Louis, MO) was applied at final concentrations of 1, 3, and $10 \mathrm{~mm}$ (Spigelman et al., 1992), and 4-aminopyridine (4-AP; Sigma) was applied at a final concentration of $100 \mu \mathrm{M}$ (Halliwell et al., 1986). Tetrodotoxin (TTX) and dendrotoxin (DTX; Research Biochemicals, Natick, MA) were applied at final concentrations of $1 \mu \mathrm{M}$ and 100, 200, and $400 \mathrm{~nm}$ (Halliwell et al., 1986), respectively. Muscarin (Sigma) was applied at a final concentration of $20 \mu \mathrm{M}$ (Halliwell and Adams, 1982). TTX $(1 \mu \mathrm{M})$ was used routinely in the voltage-clamp experiments to block voltagedependent $\mathrm{Na}^{+}$currents, unless otherwise stated.

Electrophysiology. Recording pipettes were pulled from $1.5 \mathrm{~mm}$ (external diameter) thin-walled borosilicate glass tubing (World Precision Instruments, Sarasota, FL) with a horizontal pipette puller (model P-87, Sutter Instruments, Novato, CA). Recording pipettes (1-3 M $\Omega$ ) contained the following solution (in mM): $140 \mathrm{KCl}$, 1.1 EGTA, $10 \mathrm{HEPES}$, $0.1 \mathrm{CaCl}_{2}$, and $2 \mathrm{Mg}$-ATP. The $\mathrm{pH}$ of the solution was adjusted to 7.2 with $\mathrm{KOH}(8.0 \mathrm{~N})$, resulting in a final intrapipette $\left[\mathrm{K}^{+}\right]$of $\sim 148 \mathrm{~mm}$; the osmolarity was $270-280 \mathrm{mOsm}$. The $\mathrm{K}^{+}$equilibrium potential $\left(E_{\mathrm{k}}\right)$ was calculated from the Nernst equation to be $-88 \mathrm{mV}$, assuming the complete exchange between the intracellular and intrapipette contents. In experiments in which $\mathrm{Ca}^{2+}$ was buffered and $\mathrm{Ca}^{2+}$-dependent currents were blocked, EGTA was increased to $10 \mathrm{mM}, \mathrm{KCl}$ was decreased to 130 $\mathrm{mM}$, and $\mathrm{CaCl}_{2}$ was removed from the recording pipette solution. Before recordings were performed, the pipette tips were covered with Sigmacote (Sigma) and allowed to air dry for a few seconds, which helped to decrease the pipette capacitance.

The Axopatch 1D amplifier (Axon Instruments, Foster City, CA) was used for recording in whole-cell voltage-clamp and in current-clamp modes, as already described (Sakmann and Stuart, 1995). To obtain a highresistance $(G \Omega)$ seal, we advanced the recording pipettes through the slice under positive pressure, using a piezoelectric patch-clamp manipulator (model PCS-250, Burleigh, Fishers, NY). The pipette was clamped onto the soma of the neuron at an $\sim 45^{\circ}$ angle under visual guidance. Then, negative pressure was applied to form a cell-electrode seal $(>3 \mathrm{G} \Omega)$; finally, further suction was applied to break through the membrane. The formation of the seal and breaking through the membrane were monitored on an oscilloscope (model PM3350A, Philips Electronic, Eindhoven, The Netherlands) or on a computer (Gateway 2000, Pentium 100, N. Sioux City, SD) display by observing the current response to a hyperpolarizing voltage step of 1-2 $\mathrm{mV}$. After the whole-cell recording mode was established, the resting membrane potential of the cell was recorded. The series resistance was calculated by adjusting the $C_{\mathrm{s}}$ (cell capacitance) and $R_{\mathrm{s}}$ (series resistance) potentiometers on the amplifier (Jackson, 1992). The series resistance was $7.8 \pm 0.2 \mathrm{M} \Omega(n=50)$. The $R_{\mathrm{s}}$ compensation was set at $80 \%$ (lag, $\left.10 \mu \mathrm{sec}\right)$. During whole-cell recordings the series resistance was monitored frequently and kept as stable as possible. Characteristically, for whole-cell recordings in brain slices the voltage could be clamped effectively only in the somata and in the proximal parts of the dendrites and axon, so we assume that some distortion in the recorded currents was caused by the absence of good space clamp. However, this restriction does not affect the main conclusions of this article, which emphasize qualitative distinctions between the conductance types.

In voltage-clamp experiments the holding potential was $-60 \mathrm{mV}$. No leak current was subtracted from the current traces. The input resistance of the neurons was measured in voltage-clamp experiments by stepping the membrane potential between -70 and $-80 \mathrm{mV}$, with $5 \mathrm{mV}$ increments, where the leak current is predominant. In current-clamp experiments in which the threshold for the generation of action potentials was measured, the resting membrane potential of the tested neurons was between -64 and $-69 \mathrm{mV}$, including the liquid junction potential. In those experiments in which the neurons were depolarized, they were held in this range with hyperpolarizing currents. However, those neurons with resting membrane potentials more positive than $-53 \mathrm{mV}$, including the liquid junction potential, were excluded from the analysis. The threshold for action potential generation was considered to be the membrane potential at which at least one spike was generated during gradual depolarization, using 0.1 or $0.3 \mathrm{nA}(300 \mathrm{msec})$ current steps. The membrane potential was measured at the end of the current step where it was most stable. In current-clamp experiments the bridge circuit was adjusted and checked frequently. Grounding was performed with an $\mathrm{Ag}-\mathrm{AgCl}$ reference electrode, or a $1 \%$ agar/ACSF bridge was used to complete the circuit between ACSF and the reference electrode.

Dye injections and histological processing. The morphology of the recorded neuron was verified by allowing $0.1-0.2 \%$ Lucifer yellow (Sigma) to diffuse through the pipette into the cell. The slices with Lucifer yellow-filled cells were fixed in $4 \%$ paraformaldehyde in $0.1 \mathrm{M} \mathrm{PBS}, \mathrm{pH}$ 7.4 , and refrigerated overnight before being transferred to a solution of $0.1 \mathrm{~m}$ PBS for $1 \mathrm{~d}$. The slices were cleared of water by using the solvent dimethyl sulfoxide (DMSO; Sigma), as previously described (Grace and Llinás, 1985). Stained neurons were observed and photographed on a Nikon Optiphot light microscope equipped with fluorescent attachments and a Nikon $35 \mathrm{~mm}$ camera.

Data acquisition and analysis. No correction was applied to the voltage offset observed after withdrawing the pipette from the cell $(\leq 2 \mathrm{mV})$. The correction for the liquid junction potential between the intrapipette and external solutions was obtained by placing the recording pipette in ACSF, zeroing the voltage, and measuring the potential shift produced after replacing the bath ACSF with the pipette solution. A saturated $\mathrm{KCl}$ reference electrode was used in this procedure to eliminate the change in reference electrode potential (Spigelman et al., 1992). No correction was applied to the data for the $+3 \mathrm{mV}$ potential shifts, unless stated otherwise. Decay time constants $(\tau)$ were determined by fitting (using a simplex algorithm) current recordings with single, double, or triple exponential functions of the form $I=A_{0}+A_{1} \exp \left(-t / \tau_{1}\right)+A_{2} \exp \left(-t / \tau_{2}\right)+A_{3}$ $\exp \left(-t / \tau_{3}\right)$, where $A_{0}$ to $A_{3}$ are amplitude coefficients and $\tau_{1}, \tau_{2}$, and $\tau_{3}$ are the time constants. Reversal potentials were determined by the analysis of the tail currents. The tail currents were fit to the exponential functions with one or two time constants. The first $1 \mathrm{msec}$ of the trace, which contains the 
capacitative charging transient, was omitted from the fits. Then the instantaneous outward current at the start of the step was determined by extrapolation of the exponential function to the origin (Manis and Marx, 1991). The steady-state activation or steady-state inactivation plot was fit to the Boltzmann equation in the form of $G / G_{\max }=\left\{1+\exp \left[\left(V_{1 / 2}-V\right) / K\right]\right\}^{-1}$, where $G$ is the conductance calculated by dividing the measured peak current by the driving force $\left(V-E_{\mathrm{k}}\right)$ and is normalized to its maximum value, $G_{\max } ; V$ is the step potential; $V_{1 / 2}$ is the membrane potential at half-maximal conductance; and $K$ is a constant describing the steepness of activation or inactivation. Continuous lines were fit to the data points by a Marquart-Levenberg algorithm (Spigelman et al., 1992). All of the data were stored and analyzed by pCLAMP (program 6.0.3; Axon Instruments) and Sigmaplot 3.0 software (Jandel Scientific, San Rafael, CA). Currentclamp data were digitized at $10 \mathrm{kHz}$ and filtered at $5 \mathrm{kHz}$, whereas the voltage-clamp data were digitized at $1-5 \mathrm{kHz}$ and filtered at $1-2 \mathrm{kHz}$. All of the data values are given as the mean \pm SEM. Group differences were analyzed with a Student's $t$ test for independent samples and considered to be significant with $p<0.05$.

\section{RESULTS}

The data presented in this paper were obtained from 89 cells, clearly identified as principal cells of the tangential nucleus by visualizing with an infrared camera their oval somata, which were situated between the primary vestibular fibers (Fig. 1B). Further identification was made by examining Lucifer yellow-filled principal cells. From this and previous work using Lucifer yellow and biocytin (Peusner and Giaume, 1989, 1994), it is known that the principal cells have different dendritic branching patterns. Some cells exhibit a single lateral dendrite (Fig. $1 C$ ), whereas most have multiple dendrites radiating in at least four directions. In this study the axons were always observed to course in a medial direction (Fig. 1C).

The criteria applied to select principal cells for analysis included a stable resting membrane potential of at least $-53 \mathrm{mV}$, including the liquid junction potential. The resting membrane potential of the principal cells after adjusting the liquid junction potential was $-66 \pm 0.6 \mathrm{mV}(n=89)$, and the input resistance $\left(R_{\mathrm{n}}\right)$ was $74 \pm 4 \mathrm{M} \Omega(n=30)$. None of the principal cells fired spontaneously. When depolarizing current steps were applied, three subpopulations of principal cells were distinguished in this study. The large majority $(70 \%, 62$ of 89$)$ responded to depolarizing current injections by firing a single spike (accommodating principal cells) (Fig. 2A). The threshold for spike initiation was $-37 \pm 2 \mathrm{mV}(n=20)$, including the liquid junction potential. In $13 \%$ (12 of 89 ) of the principal cells, an action potential could not be initiated from the resting membrane potential, even after large depolarizations (silent principal cells; Fig. $2 B$ ). In contrast, $17 \%$ (15 of 89 ) of the principal cells were capable of firing multiple spikes in response to depolarizing current injections (nonaccommodating principal cells; Fig. $2 C$ ), and their threshold (-48 \pm 2 $\mathrm{mV}$, including the liquid junction potential; $n=10)$ for activation of the action potential was significantly $(p<0.05)$ lower than that observed for the principal cells firing a single spike. From Lucifer yellow injections no significant differences in the morphology of these three physiologically distinctive populations of principal cells were observed. Furthermore, these subpopulations of principal cells exhibited no significant differences in either their resting membrane potentials or input resistances. Because the vast majority of principal cells at E16 belongs to the subclass of cells firing only one spike in response to depolarizing current, this study is focused on identifying the membrane currents underlying this distinctive firing pattern.

\section{Separation of the outward and inward currents}

In voltage-clamp experiments the depolarization of the accommodating $(n=6)$ (Fig. $3 A 1)$ and nonaccommodating principal
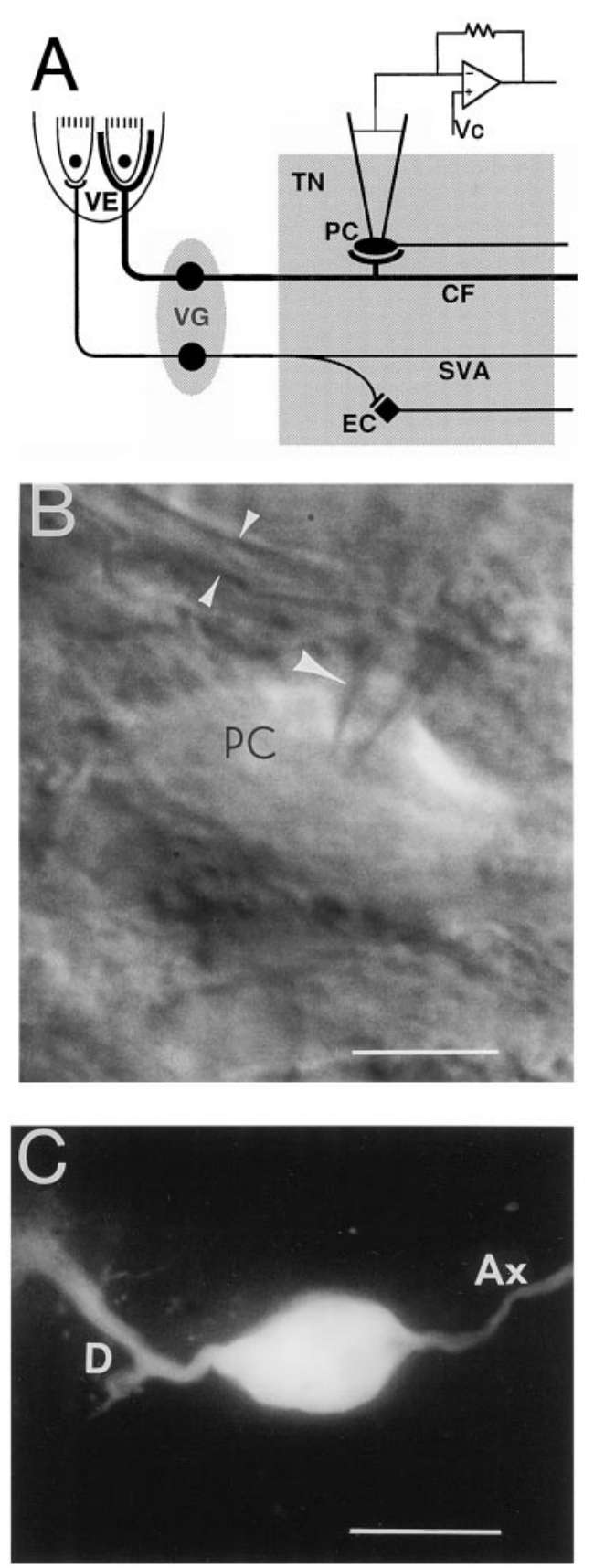

Figure 1. A, Diagram of chick tangential nucleus and peripheral vestibular apparatus. Somata of first-order vestibular neurons are located in the vestibular ganglia $(V G)$ and relay impulses from hair cells in the vestibular epithelium $(V E)$ to second-order vestibular neurons located in the tangential nucleus $(T N)$. The largest vestibular afferents, the colossal fibers $(C F)$, form large calyx-like spoon terminals on the principal cells $(P C)$ of the nucleus. The elongate cells $(E C)$ compose $<20 \%$ of the tangential neurons and receive input only from the small vestibular afferents (SVA). $V c$, Voltage command. $B$, Infrared camera image of a principal cell $(P C)$ during a recording. A single arrow indicates the patch electrode, and the double arrows indicate a colossal fiber. Calibration bar, $15 \mu \mathrm{m}$. C, A principal cell after Lucifer yellow injection. Different cells are shown in $B$ and $C$. $D$, Dendrite; $A x$, axon. Calibration bar, $30 \mu \mathrm{m}$.

cells ( $n=4$; data not shown) induced a large, inward transient current on the order of $2 \mathrm{nA}$, which could be blocked by $1 \mu \mathrm{M}$ TTX (Fig. 3B). In addition, in current-clamp experiments TTX blocked the generation of action potentials in accommodating 

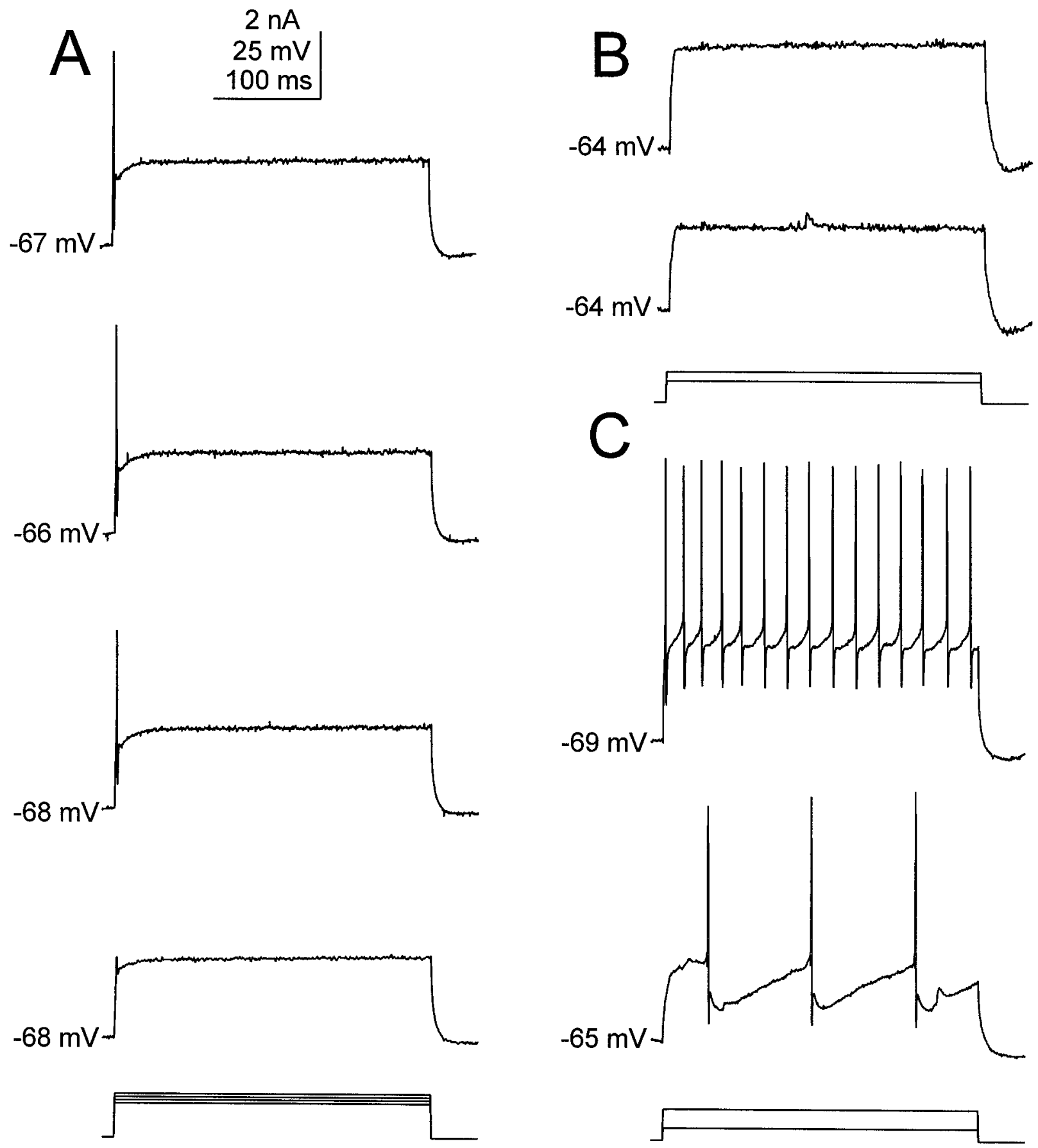

Figure 2. Current-clamp recordings of the responses to depolarization pulses of physiologically different subpopulations of principal cells. $A$, The vast majority of principal cells responds to current injection (bottom traces) by firing a single action potential, followed by accommodation (top traces). $B$, Silent principal cells do not fire action potentials from resting membrane potential, even after a large depolarization. $C$, Some principal cells can fire multiple action potentials on depolarization. Calibration bars apply to $A-C$.

principal cells $(n=3$; data not shown). These experiments indicate that sodium channels are responsible for the generation of action potentials in embryonic principal cells. In those principal cells that did not generate action potentials on depolarization after voltage steps more positive than $-40 \mathrm{mV}$, these cells exhibited an inward deflection in the outward current (Fig. 3A2), which was blocked by $1 \mu \mathrm{M}$ TTX $(n=2)$. The TTX effect suggests that the silent principal cells also express sodium channels, which are insufficient to generate action potentials. In accommodating prin- cipal cells exposed to TTX, the outward transient current was decreased significantly (Fig. 3B, inset), suggesting that principal cells possess a $\mathrm{Na}^{+}$-dependent $\mathrm{K}^{+}$current, as described in avian brainstem neurons and peripheral ganglia (Bader et al., 1985; Dryer et al., 1989). However, the presence of a space-clamp problem in this preparation prevents drawing a definitive conclusion (Dryer et al., 1989).

Some principal cells demonstrated inward rectification on hyperpolarization, which activated at potentials more negative than 

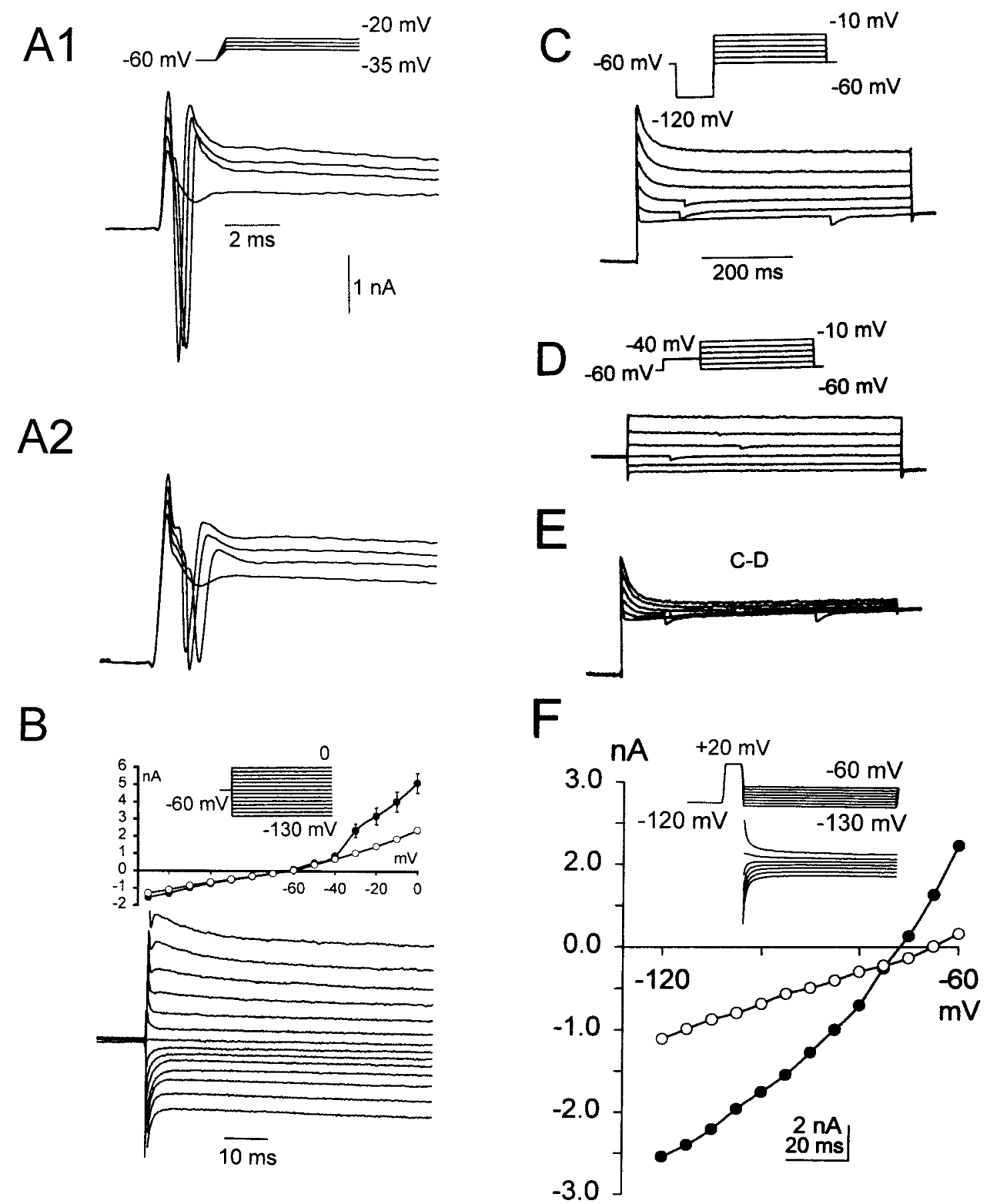

Figure 3. Whole-cell patch-clamp recordings of the inward and outward currents. Current traces are shown at the same scale, whereas the time base was varied, as indicated in the calibration bars. $A 1, A 2$, Current traces (bottom traces) from accommodating $(A 1)$ and silent principal cells $(A 2)$ elicited by $5 \mathrm{mV}(20 \mathrm{msec})$ voltage steps from -35 to $-20 \mathrm{mV}$ (top traces), performed in control ACSF. B, Current traces in accommodating principal cell (bottom traces) elicited by $10 \mathrm{mV}(80 \mathrm{msec}$ ) voltage steps from $-130 \mathrm{mV}$ to 0 voltage (top traces in inset), performed in ACSF containing $1 \mu \mathrm{M}$ TTX. Inset, Current-voltage curve of peak current in accommodating principal cells, measured between 3 and 6 msec after onset of voltage steps in control ACSF $(\bullet)(n=4)$ and in the presence of $1 \mu \mathrm{M}$ TTX $(\bigcirc)(n=4)$. There was a significant difference $(p<0.05)$ in outward current amplitude from -30 to 0 $\mathrm{mV}$ before and after TTX application. This suggests the presence of a Na-dependent outward current. All of the subsequent recordings were performed in the presence of TTX. $C$, Current traces (bottom traces) elicited by using $600 \mathrm{msec}$ voltage steps from -60 to $-10 \mathrm{mV}$, with $10 \mathrm{mV}$ increments preceded by a $200 \mathrm{msec}$ prestep to $-120 \mathrm{mV}$ (top traces). Transient and sustained components can be observed in the current traces in addition to spontaneous EPSCs in $C-E$. $C-E$ are shown at the same time base. $D$, Current traces (bottom traces) elicited by using $600 \mathrm{msec}$ voltage steps from -60 to $-10 \mathrm{mV}$, with $10 \mathrm{mV}$ increments. The steps are preceded by a $200 \mathrm{msec}$ prestep to $-40 \mathrm{mV}$ (top traces). The transient current was inactivated entirely by the prestep. $E$, Transient current obtained by subtraction of $D$ from $C$. F, Instantaneous current-voltage curve $(\bullet)$ obtained by extrapolating the tail current at the onset of the testing voltage step, and the steady-state current-voltage curve $(\bigcirc)$ obtained by measuring the current amplitude at the end of testing voltage steps. The intersection of the two curves indicates the reversal potential at $-75 \mathrm{mV}(-78 \mathrm{mV}$ after adjustment of the liquid junction potential). Inset, Reversal of the tail currents with voltage (bottom traces). The total current was activated by a $6 \mathrm{msec}$ voltage step to $+20 \mathrm{mV}$, which was preceded by a $200 \mathrm{msec}$ prestep to $-120 \mathrm{mV}$ (top traces). Reversal of the tail currents was analyzed by using $50 \mathrm{msec}$ test potentials from -60 to $-130 \mathrm{mV}$, with $10 \mathrm{mV}$ increments. 
$-80 \mathrm{mV}$ (Fig. 3B). Leak conductance was predominant between -60 and $-80 \mathrm{mV}$. We considered a cell to be damaged if the amplitude of the leak current induced by stepping the membrane potential from -70 to $-80 \mathrm{mV}$ exceeded $0.3 \mathrm{nA}$, and these cells were excluded from further analysis.

All of the principal cells exhibited outward currents composed of both transient and sustained components in the presence of TTX (Fig. 3B,C). The separation of the outward transient and sustained currents was achieved with a standard subtraction procedure that was based on their different voltage dependencies (Spigelman et al., 1992; Klee et al., 1995). After 200 or $800 \mathrm{msec}$ presteps at potentials near $-40 \mathrm{mV}$ (Fig. $3 D$ ), only sustained currents were elicited, and they were subtracted from the total currents activated after a $200 \mathrm{msec}$ prestep to $-120 \mathrm{mV}$ (Fig. 3C) or after an $800 \mathrm{msec}$ prestep to $-100 \mathrm{mV}(n=15)$. The isolated transient currents are shown in Figure $3 E$. Because of run-down of the calcium current and, subsequently, the calcium-dependent outward sustained currents, a fraction of the sustained currents was present in the remaining currents obtained by the subtraction procedure. Indeed, in the presence of calcium channel blockers $\left(\mathrm{Cd}^{2+}\right.$ and $\left.\mathrm{Co}^{2+}\right)$ or in 0 calcium solution, the sustained currents were not observed in the isolated currents when $200 \mathrm{msec}$ presteps were used for separation $(n=5)$. However, when $800 \mathrm{msec}$ presteps were used, part of the DTX-sensitive sustained current $\left(I_{\mathrm{DS}}\right)$ inactivated as well.

To characterize the ionic basis of the outward currents, we investigated their reversal potential $\left(E_{\mathrm{r}}\right)$. An outward current, composed of both transient and sustained components, was evoked by a $6 \mathrm{msec}$ test pulse to $+20 \mathrm{mV}$, which was preceded by a prestep to $-120 \mathrm{mV}$. Then the cell was repolarized to various potentials (Fig. $3 F$, inset). The value of $E_{\mathrm{r}}$ was determined from a plot of the current-voltage relationship by identifying the membrane potential at which the instantaneous and steady-state currents intersect (Fig. 3F) (Manis and Marx, 1991). The instantaneous current-voltage relation is not linear, which may be attributed to an underestimation of the currents at negative potentials, where they decline rapidly (Fig. $3 F$ ). The reversal potential of the outward currents of accommodating principal cells is $-72 \pm 2 \mathrm{mV}$, including the liquid junction potential $(n=$ $8)$. In two cases the reversal potentials of the sustained currents were calculated. In these cases a longer test step (150 msec) was applied, during which the transient currents inactivated. The calculated values of $E_{\mathrm{r}}$ for the sustained currents were -75 and $-68 \mathrm{mV}$, including the liquid junction potential, which are in good agreement with the $E_{\mathrm{r}}$ value for the total outward currents $(-72 \mathrm{mV})$. The equilibrium potential for chloride $\left(E_{\mathrm{Cl}}\right)$ in our recording solution was $+1.3 \mathrm{mV}$. Thus, the calculated reversal potential for the outward currents is near the theoretical equilibrium potential for potassium $\left(E_{\mathrm{K}}\right)$ of $-88 \mathrm{mV}$. To investigate further the ionic species carrying the outward currents, we raised the extracellular potassium concentration from 5 to $50 \mathrm{~mm}$. This procedure shifted $E_{\mathrm{K}}$ to $-28 \mathrm{mV}$, and the outward current $E_{\mathrm{r}}$ shifted to $-40 \pm 3 \mathrm{mV}$, including the liquid junction potential $(n=3)$. The $E_{\mathrm{r}}$ value of the outward currents in normal ACSF and its shift in direction to the new $E_{\mathrm{K}}$ in ACSF containing a high potassium concentration suggest that at least part of the outward current is carried by potassium ions in accommodating principal cells. Also, when we tested the reversal potential of the outward current in silent $(n=2)$ and in nonaccommodating principal cells $(n=3)$, we observed no significant differences in the $E_{\mathrm{r}}$ between these subpopulations and the accommodating principal cells.

\section{Transient outward current kinetics and its role in spike generation}

To investigate the role of the transient outward current in accommodation and the ability of second-order vestibular neurons to generate action potentials, we analyzed steady-state activation, inactivation, and the removal of inactivation from this current in the different subpopulations of principal cells. The decay rate of the transient current at 0 potential in every tested principal cell $(n=$ 13) was best fit by two or sometimes three exponentials, which suggests that more than one type of channel is responsible for the transient current (Hille, 1992). The slowest time constant $(\tau)$ was placed between 30 and $180 \mathrm{msec}(n=13)$. Steady-state activation of the transient current was investigated by isolating this current from the total current, as already described (Fig. 3C-E). Normalized conductance values for steady-state activation of the transient current from accommodating principal cells are shown in Figure $4 A$. Steady-state inactivation of the transient current was investigated by evoking currents with a fixed depolarizing command to $+10 \mathrm{mV}$, which was preceded by hyperpolarizing prepulses to various potentials (Fig. 4B, inset). Normalized conductance values for steady-state inactivation of the transient current from accommodating principal cells is shown in Figure $4 B$. The steady-state activation and inactivation data obtained from the various subpopulations of principal cells were fit by the Boltzmann equation, and the values for $V_{1 / 2}$ and $K$ have been calculated (Table 1 ). To test the removal of inactivation from the transient current in accommodating and nonaccommodating principal cells, we held the neurons for $200 \mathrm{msec}$ at $-40 \mathrm{mV}$ to inactivate the transient currents completely. Then hyperpolarizing voltage commands of varying durations were applied, which were followed by a fixed test pulse to $+10 \mathrm{mV}$ (Fig. $4 C$, inset). Near-complete activation of the transient current was observed with prepulse durations $>10 \mathrm{msec}$. The time constant for removal of the inactivation was obtained by fitting the data points with an exponential function in the form ( $I-$ $\left.I_{\mathrm{s}}\right) /\left(I_{\max }-I_{\mathrm{s}}\right)=[1-\exp (-t / a)]$, where $\left(I-I_{\mathrm{s}}\right) /\left(I_{\max }-I_{\mathrm{s}}\right)$ is the transient current amplitude normalized to its maximum value ( $I_{\max }$ $\left.-I_{\mathrm{s}}\right), I_{\mathrm{s}}$ is the sustained current amplitude, $t$ is the prepulse duration, and $a$ is the time constant for removal of inactivation (Fig. $4 C$ ). In those principal cells that fire either single or multiple action potentials, the mean time constant for removal of inactivation was $3.3 \pm 0.6 \mathrm{msec}(n=5)$ or $3.1 \pm 0.6 \mathrm{msec}(n=3)$, respectively. No significant difference was found among the kinetics of steady-state inactivation, activation, or removal of inactivation of the transient currents from these different subpopulations of principal cells. Further, in the different subpopulations we have not observed significant differences in the amplitude of the transient current, which could vary from 0.6 to $3 \mathrm{nA}$. The similarities in the kinetics of the transient currents observed in the different subpopulations of the principal cells suggest that this current does not contribute to the accommodation response observed in most of the principal cells. In fact, in current-clamp experiments the depolarization of the principal cells with current steps (from +0.1 to +1.6 $\mathrm{nA}$ ), which were preceded by $300-800 \mathrm{msec}$ presteps to $-40 \mathrm{mV}$ that entirely inactivated the transient current, did not alter the accommodation response for these cells. They were still capable of firing only a single action potential $(n=4)$, and we did not observe a change in their firing threshold. However, in the case of the silent cells, after presteps to $-40 \mathrm{mV}$, depolarization could trigger a single action potential (Fig. $5 A, B)(n=3)$. These experiments strongly suggest that the transient current is not responsible for the accommodation observed in the majority of principal cells. How- 


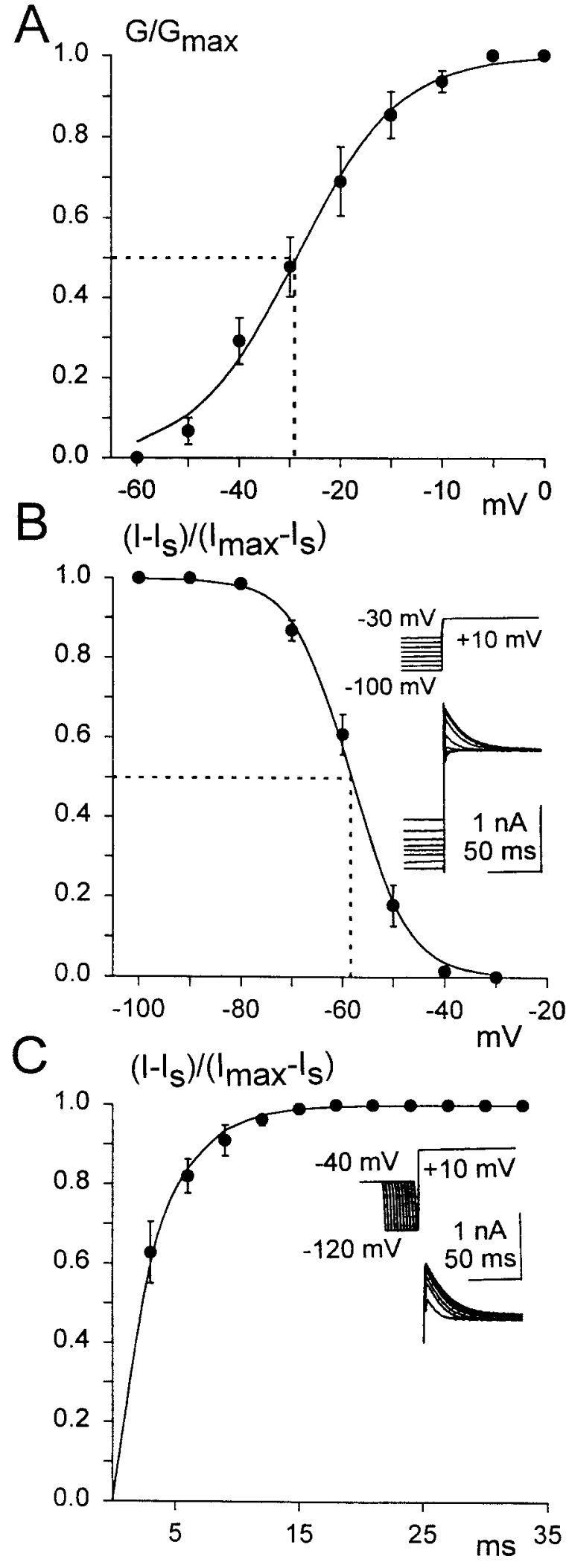

Figure 4. A, Steady-state activation of the transient current from an accommodating principal cell, plotted as a function of the membrane potential. Averaged, normalized conductance values were fit with the Boltzmann equation. Conductance $(G)$ values were calculated by dividing the measured peak transient current by the driving force $\left(V-E_{\mathrm{k}}\right)$. The dotted line indicates $V_{1 / 2}=-29 \pm 3 \mathrm{mV}$. B. Steady-state inactivation of the transient current. Averaged, normalized conductance values were fit

\begin{tabular}{lll}
\hline \multicolumn{2}{l}{ Table 1. Half-maximal potentials and slope coefficients } \\
$\begin{array}{lll}\text { Principal cell } \\
\text { populations }\end{array}$ & $\begin{array}{l}\text { Steady-state } \\
\text { activation }\end{array}$ & $\begin{array}{l}\text { Steady-state } \\
\text { inactivation }\end{array}$ \\
\hline Accommodating & $V_{1 / 2}^{1 / 2}=-32 \pm 3.2 \mathrm{mV}$, & $V^{1 / 2}=-61 \pm 1.2 \mathrm{mV}$, \\
$(n=8)$ & $K=8.8 \pm 0.8 \mathrm{mV}$ & $K=5.1 \pm 0.4 \mathrm{mV}$ \\
Nonaccommodating & $V_{1 / 2}=-34 \pm 3.1 \mathrm{mV}$, & $V_{1 / 2}^{1 / 2}=-62 \pm 5 \mathrm{mV}$, \\
$(n=4)$ & $K=6.8 \pm 1.0 \mathrm{mV}$ & $K=5.5 \pm 0.4 \mathrm{mV}$ \\
Silent & $V_{1 / 2}^{1 / 2}=-35 \pm 3.0 \mathrm{mV}$, & $V_{1 / 2}^{1 / 2}=-64 \pm 1.3 \mathrm{mV}$, \\
$(n=3)$ & $K=5.7 \pm 1.1 \mathrm{mV}$ & $K=4.0 \pm 0.8 \mathrm{mV}$
\end{tabular}

Half-maximal potentials $\left(V_{1 / 2}\right)$ and slope coefficients $(K)$ were obtained by fitting the normalized conductance values for steady-state activation and inactivation of the transient current from different subpopulations of principal cells to the Boltzmann equation (see Fig. 4A,B). The $V_{1 / 2}$ values include the liquid junction potential and represent means \pm SEM. The values of $V_{1 / 2}$ and $K$ for steady-state activation and inactivation were not significantly different among the three distinct subpopulations of principal cells investigated $(p>0.05)$.

ever, a small group of principal cells, the silent ones, may be prevented from firing a single action potential by the transient current.

\section{Sustained outward currents}

To determine whether the sustained outward current contributes to the accommodation observed in most principal cells, we compared the amplitudes of sustained currents obtained from accommodating and nonaccommodating principal cells. Although there was no significant difference in current values obtained at voltages more negative than $-60 \mathrm{mV}$, significant differences $(p<0.05)$ were observed in the amplitudes of the sustained outward currents that activated at potentials between -60 and $0 \mathrm{mV}$ (Fig. 6). This suggests that these two groups of principal cells express different sustained outward currents, which could contribute to their distinctive firing patterns. Accordingly, further identification of the sustained outward currents was performed.

\section{Calcium-dependent potassium currents}

The presence of a calcium-dependent outward potassium current was investigated in accommodating principal cells by using ACSF solution containing (1) $300 \mu \mathrm{M} \mathrm{CdCl}_{2}(n=5)$, (2) $0 \mathrm{Ca}^{2+}$ and 2 mu cobalt $(n=3)$, or (3) $0 \mathrm{Ca}^{2+}(n=5)$. In all of these modified ACSF solutions both the sustained and the transient currents were reduced in amplitude (Fig. 7). The plot of the normalized amplitude of the sustained current in accommodating principal cells before and after exposure to modified ACSF (Fig. 7B) suggests that this subpopulation of principal cells expresses a calciumdependent sustained potassium current, which activates at potentials more positive than $-20 \mathrm{mV}$. To rule out the possibility that the

$\leftarrow$

with the Boltzmann equation. Normalized conductance values for the transient current were obtained by measuring the peak amplitude of the total current $(I)$, subtracting the sustained current amplitude $\left(I_{\mathrm{s}}\right)$, and then dividing by the total current maximum amplitude $\left(I_{\max }\right)$ minus the sustained current $\left(I_{\mathrm{s}}\right)$. The dotted line indicates $V_{1 / 2}=-58 \pm 1.2 \mathrm{mV}$. Inset, Current traces (bottom traces) elicited by voltage steps to + $10 \mathrm{mV}$, which were preceded by $200 \mathrm{msec}$ voltage presteps from -30 to $-100 \mathrm{mV}$, with $10 \mathrm{mV}$ increments (top traces). $C$, Plot of averaged, normalized peak transient current versus the duration of the hyperpolarizing prepulse, fit with an exponential function. Inset, Transient current traces (bottom traces) elicited by stepping the membrane potential to +10 , preceded by different duration hyperpolarizing presteps to $-120 \mathrm{mV}$, which were preceded by a $200 \mathrm{msec}$ prepotential to $-40 \mathrm{mV}$. The normalized transient current value was calculated from the total peak current $(I)$ by subtracting the sustained current $\left(I_{\mathrm{s}}\right)$ and dividing by the total current maximum value $\left(I_{\max }\right)$ minus the sustained current $\left(I_{\mathrm{s}}\right)$. 

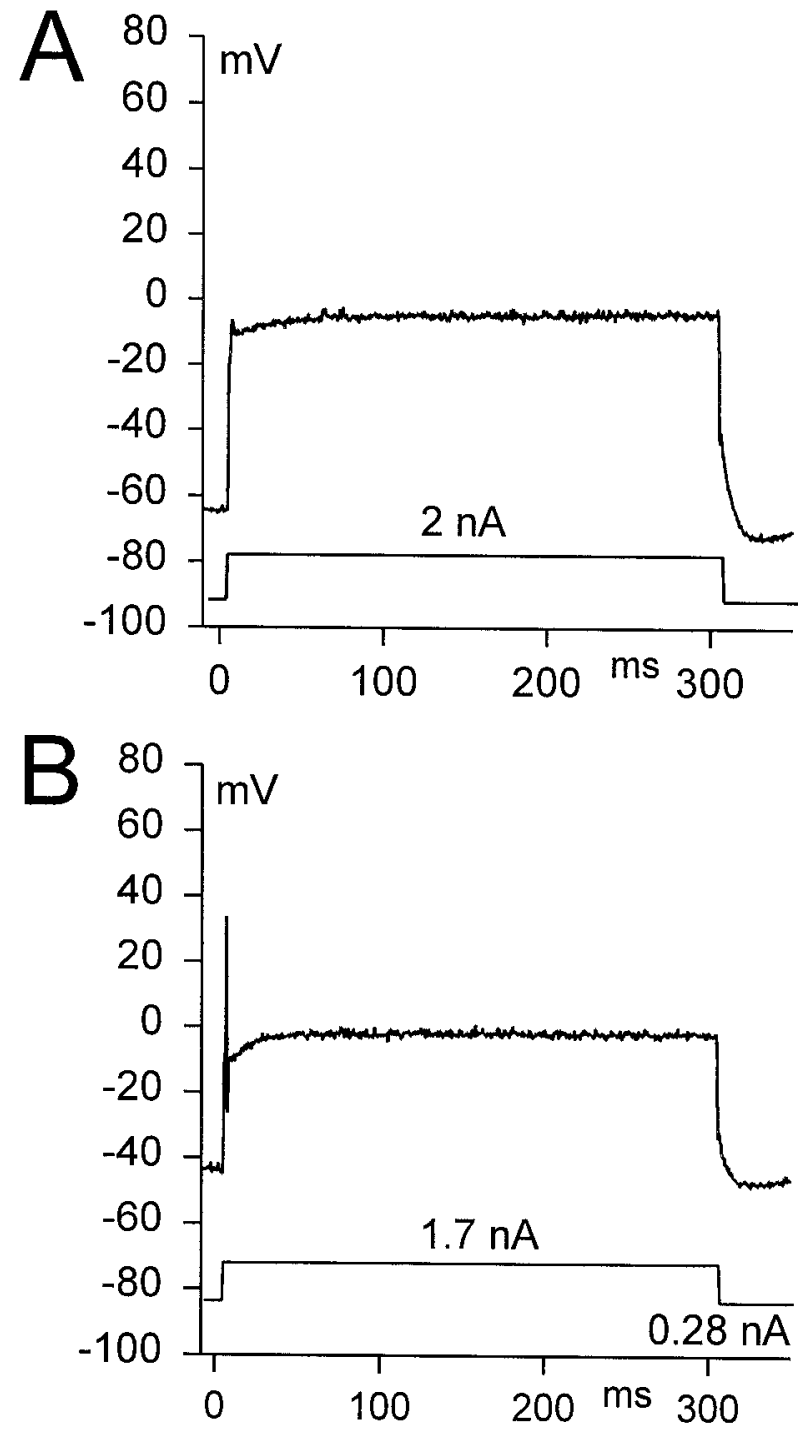

Figure 5. Current-clamp recordings of the effect of transient current inactivation on action potential generation in a silent principal cell. $A$, Depolarization of the silent principal cell (top trace) elicited by $300 \mathrm{msec}$ current injection ( $2 \mathrm{nA}$; bottom trace) from its resting membrane potential $(-67 \mathrm{mV}$, including the liquid junction potential) to approximately -10 $\mathrm{mV}$ did not generate an action potential. $B$, After a $300 \mathrm{msec}$ prestep close to $-40 \mathrm{mV}$ (induced by $0.28 \mathrm{nA}$ holding current), the same depolarization could trigger a single action potential.

apparent decrease of the sustained current amplitude in modified ACSF was attributable to a shift in its steady-state activation curve along the voltage axis, we plotted normalized conductances versus membrane potential in normal and modified ACSF (Fig. 7B, inset). When the Boltzmann equation was fit to the data $\left(V_{1 / 2}=-28.7 \pm\right.$ $3 \mathrm{mV}, K=13.4 \pm 0.4$ in normal ACSF; $V_{1 / 2}=-26.4 \pm 2 \mathrm{mV}, K=$ $14.3 \pm 0.6 \mathrm{mV}$ in modified ACSF), we did not observe a significant shift of the steady-state activation curve. This finding further supports the conclusion that the decrease of the sustained current amplitude in modified ACSF was attributable to blocking a calcium-dependent sustained current. In contrast, the decrease of the transient current amplitude in the presence of modified ACSF solution, containing the divalent cations $\mathrm{Cd}^{2+}$ or $\mathrm{Co}^{2+}$, was associated with shifts in both the steady-state activation and inactivation curves $(n=5)$, which may reflect the interaction of these

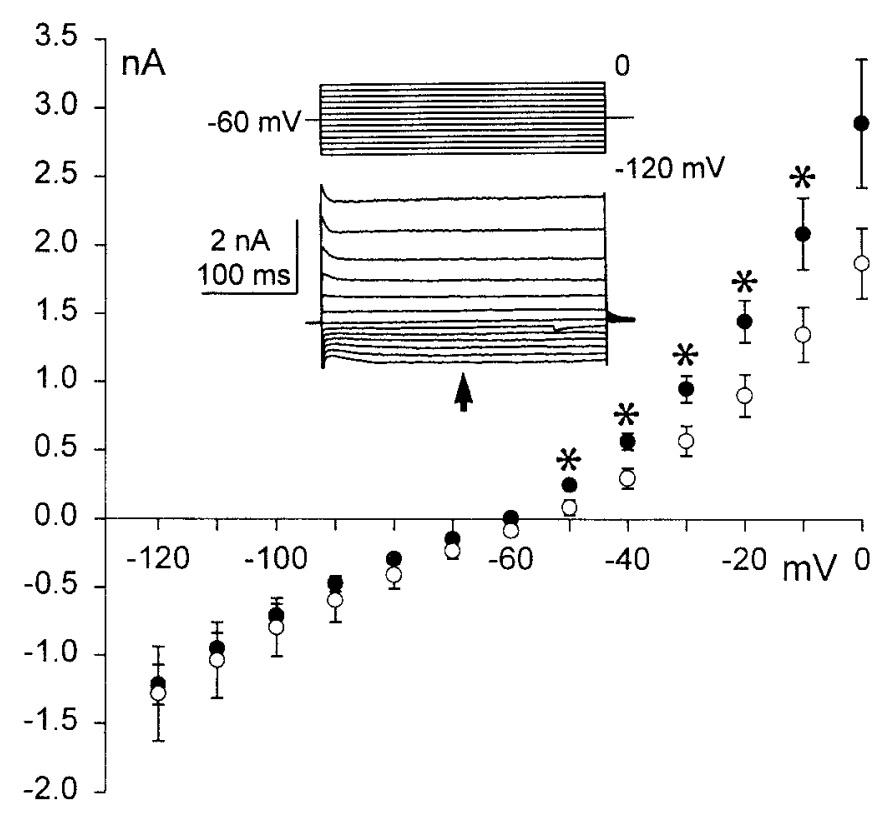

Figure 6. Current-voltage curves of the sustained currents observed for repetitive firing $(\bigcirc, n=8)$ and accommodating principal cells $(\boldsymbol{O}, n=5)$. The sustained current amplitude was measured $150 \mathrm{msec}$ after the onset of the voltage steps from the $-60 \mathrm{mV}$ holding potential (see inset). The current amplitudes between -60 and $0 \mathrm{mV}$ potentials were significantly different $(p<0.05)$. An asterisk indicates points of significant difference. Inset, An example of current recordings (bottom traces) from an accommodating principal cell used to draw the $I-V$ curve (an arrow indicates the point at which the current amplitude was measured). The currents were induced by stepping the membrane potential from $-120 \mathrm{mV}$ to 0 potential with $10 \mathrm{mV}$ increments (top trace).

divalent cations with the transient current channels (Mayer and Sugiyama, 1988). However, the $0 \mathrm{Ca}^{2+}$-modified ACSF did not cause a shift in either the steady-state activation or inactivation curves but did produce a decrease in the transient current amplitude (Fig. 7C), suggesting that part of this current is calciumdependent. Finally, the absence of good space clamp in this preparation makes it difficult to draw a definite conclusion (Rudy, 1988). Using calcium-free and cobalt-containing ACSF, we also identified a calcium-dependent sustained potassium current in the silent $(n=$ 2 ) and nonaccommodating $(n=2)$ principal cells (data not shown).

To investigate the role of calcium-dependent potassium currents in the accommodation of the principal cells, we examined action potentials firing on depolarization in calcium-free ACSF or in calcium-free and cobalt-containing ACSF. The EGTA concentration in the recording pipette was increased from 1.1 to $10 \mathrm{mM}$ to enhance the calcium buffering inside the cells. During recording in normal ACSF with pipettes containing a high concentration of EGTA, accommodation was still observed $(n=10)$. Furthermore, long exposures $(20 \mathrm{~min})$ to modified ACSF did not alter the response to depolarization of accommodating or silent principal cells. For this purpose, recordings were performed in the absence of external calcium for both classes of cells (silent cells, $n=4$; accommodating cells, $n=3$ ) and by substituting $\mathrm{Co}^{2+}$ for $\mathrm{Ca}^{2+}$ in ACSF for accommodating cells $(n=3)$. Together, these observations indicate that the calcium-dependent potassium currents were not involved in the observed accommodation and were not responsible for the silence of some principal cells.

Subsequent analyses of the sustained currents were performed in calcium-free ACSF with recording pipettes containing $10 \mathrm{~mm}$ 


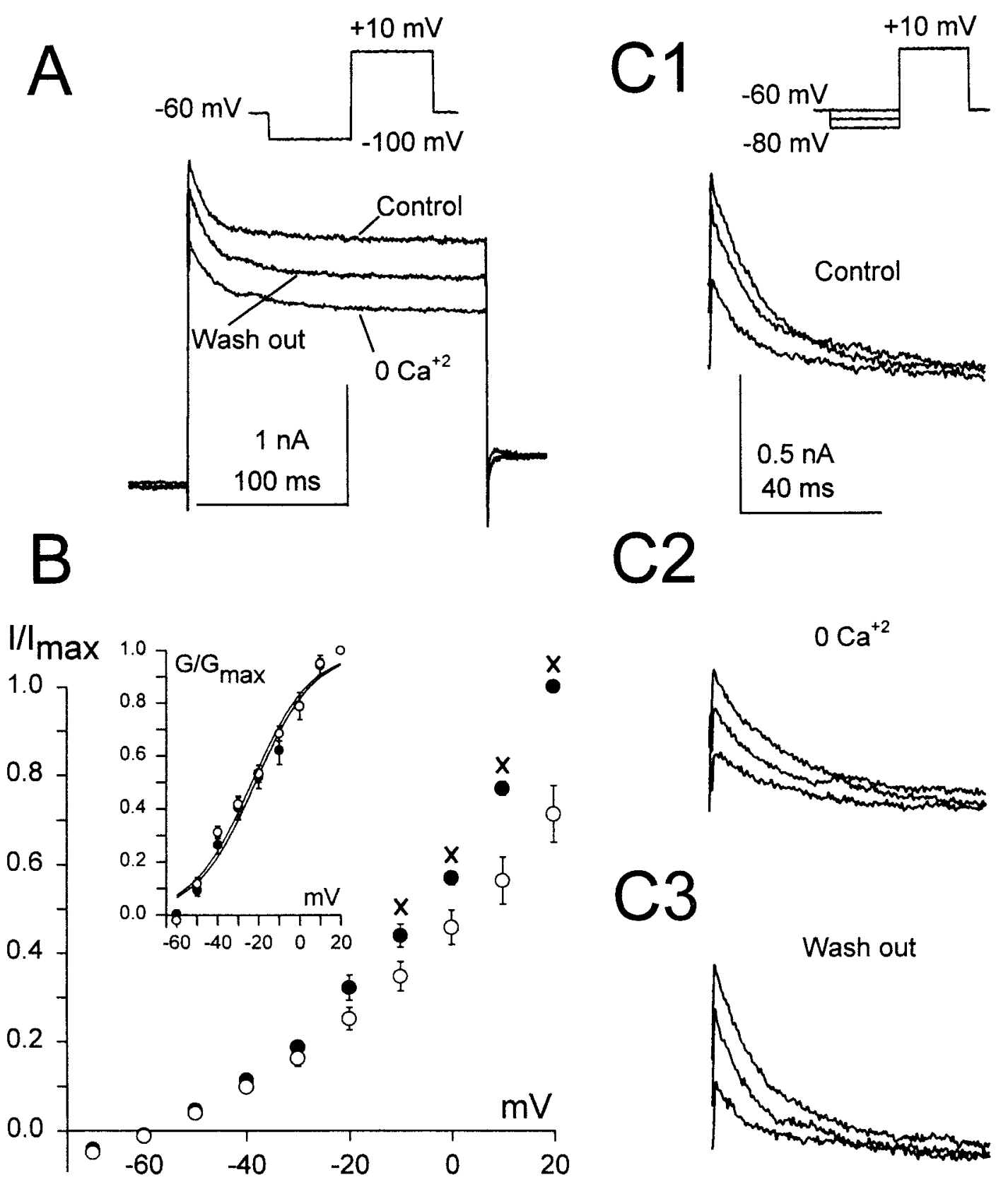

Figure 7. $\mathrm{Ca}^{2+}$-dependent outward currents in accommodating principal cells. A, Current traces (bottom traces) elicited in normal (Control), $0 \mathrm{Ca}{ }^{2+}$ $\mathrm{ACSF}$, and wash-out solution, using $200 \mathrm{msec}$ voltage steps to $+10 \mathrm{mV}$, preceded by a $200 \mathrm{msec}$ voltage prestep to $-100 \mathrm{mV}$ (top traces). $B$, Averaged, normalized sustained current amplitude in $0 \mathrm{Ca}^{+2} \mathrm{ACSF}(n=5), 3 \mathrm{mM} \mathrm{CoCl}_{2} \mathrm{ACSF}(n=5)$, or $300 \mu \mathrm{M} \mathrm{CdCl}_{2} \mathrm{ACSF}(\bigcirc, n=3)$ and in normal $\mathrm{ACSF}$ $(\bullet, n=13)$ versus membrane potential. The currents were measured at the end of $600 \mathrm{msec}$ voltage steps applied with $10 \mathrm{mV}$ increments from -70 to $+20 \mathrm{mV}$, preceded by a $800 \mathrm{msec}$ prestep to $-100 \mathrm{mV}$. There were significant differences $(p<0.05)$ between the current amplitudes started at $-10 \mathrm{mV}$ and continuing through $+20 \mathrm{mV}$. $X$ indicates points of significant difference. Inset, Plot of averaged, normalized conductances versus membrane potential for the same principal cells as shown in the $I-V$ curves in normal $(\bullet)$ and modified ACSF $(O)$. The Boltzmann equation was fit to the data $\left(V_{1 / 2}=\right.$ $-28.7 \pm 3 \mathrm{mV}, K=13.4 \pm 0.4$ in normal ACSF and $V_{1 / 2}=-26.4 \pm 2 \mathrm{mV}, K=14.3 \pm 0.6 \mathrm{mV}$ ) in modified ACSF. The liquid junction potential was included. The current-amplitude measurements necessary for the conductance calculations were the same ones used to draw the $I-V$ curves. $C 1-C 3$, Transient current traces (bottom traces) from the same cell as shown in $A$, induced by stepping the membrane potential to $+10 \mathrm{mV}$ and preceded by $200 \mathrm{msec}$ presteps to $-60,-70$, and $-80 \mathrm{mV}$ (top traces); $C 1$, performed in normal ACSF (Control); $C 2$, in $0 \mathrm{Ca}^{2+} \mathrm{ACSF}$; 3 , in control solution (Wash out).

EGTA to avoid interference from run-down of the calciumdependent currents and also to block synaptic transmission.

High-threshold sustained potassium current

A high-threshold, calcium-independent sustained current was identified in the principal cells by using 1-3 mM TEA. In those principal cells that fire either a single spike $(n=6)$ or none at all $(n=4)$, TEA blocked reversibly a slowly activating, noninactivating portion of the outward potassium current (Fig. 8A-C). Even during a $16 \mathrm{sec}$ voltage step the TEA-sensitive current, activated by stepping the membrane potential to $-10 \mathrm{mV}$, did notdisplay significant inactivation ( $n=2$; data not shown). In accommodating and silent principal cells, TEA blocked similar 


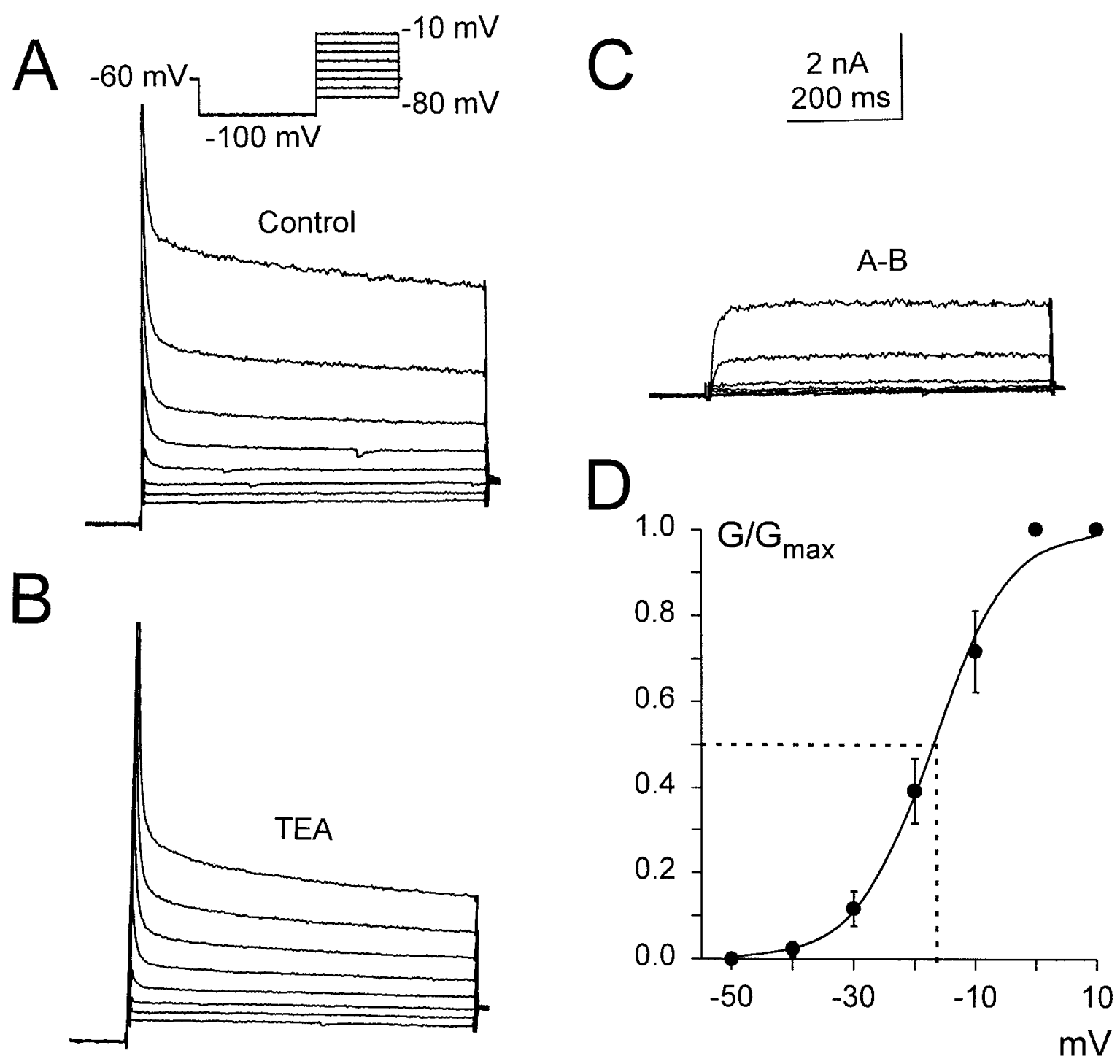

Figure 8. Effect of tetraethylammonium (TEA) on the outward currents in accommodating and silent principal cells. Shown are outward currents (bottom traces) in $0 \mathrm{Ca}^{2+}$ ACSF $\left(A\right.$, Control) and in $0 \mathrm{Ca}^{2+}$ ACSF containing $3 \mathrm{~mm}$ TEA $(B)$. The currents were induced by using $600 \mathrm{msec}$ voltage steps from -80 to $-10 \mathrm{mV}$, with $10 \mathrm{mV}$ increments preceded by an $800 \mathrm{msec}$ prestep to $-100 \mathrm{mV}$ (top traces). $C$, Current traces obtained by subtraction of $B$ from $A$. $D$, Steady-state activation of averaged $(n=10)$ and normalized TEA-sensitive current as a function of membrane potential. The Boltzmann equation was fit to the data. The TEA-sensitive current amplitude, necessary for the conductance calculation, was measured 300 msec from the onset of the voltage steps. The dotted line indicates $V_{1 / 2}=-16 \pm 2.2 \mathrm{mV}$.

portions of the current. Therefore, the data for steady-state activation from these two subpopulations have been combined (Fig. $8 D)$. The high-threshold, TEA-sensitive current activated at potentials between -45 and $-35 \mathrm{mV}$; the $V_{1 / 2}$ for activation was $-19 \pm 2.2 \mathrm{mV}$, including the liquid junction potential, and $K$ was $5.3 \pm 0.5 \mathrm{mV}(n=10)$. Also, we have observed high-threshold, TEA-sensitive current in nonaccommodating principal cells $(n=2)$.

In current-clamp experiments the exposure of the accommodating $(n=3)$ or silent principal cells $(n=3)$ to calcium-free, cobalt-containing or to a calcium-free ACSF that also contained $3 \mathrm{~mm}$ TEA did not alter their responses to depolarization. The continued accommodation of these principal cells treated with modified ACSF and TEA was not attributable to damage, because in the presence of $200 \mathrm{~nm}$ DTX these neurons could fire trains of action potentials on depolarization $(n=2$; data not shown). Thus, the current-clamp data suggest that calcium- dependent and calcium-independent TEA-sensitive currents do not play a major role in accommodation of the principal cells.

\section{Low-threshold potassium current}

In different slice preparations DTX in nanomolar concentrations has been demonstrated to block specifically a low-threshold potassium current (Halliwell et al., 1986; Brew and Forsythe, 1995). In the present study the results obtained by the application of various concentrations (100, 200, and $400 \mathrm{~nm}$ ) of DTX (synthesized $\alpha$-DTX) indicate that both accommodating $(n=10)$ and silent principal cells $(n=4)$ possess a DTX-sensitive, lowthreshold potassium current. Indeed, DTX blocked part of the sustained and a small portion of the transient current in these cells (Fig. $9 A-C$ ), suggesting that possibly more than one type of DTX-sensitive channel is present in these neurons. In all cases the effect of DTX was irreversible, as reported in other preparations (Halliwell et al., 1986; Brew and Forsythe, 1995). Further 

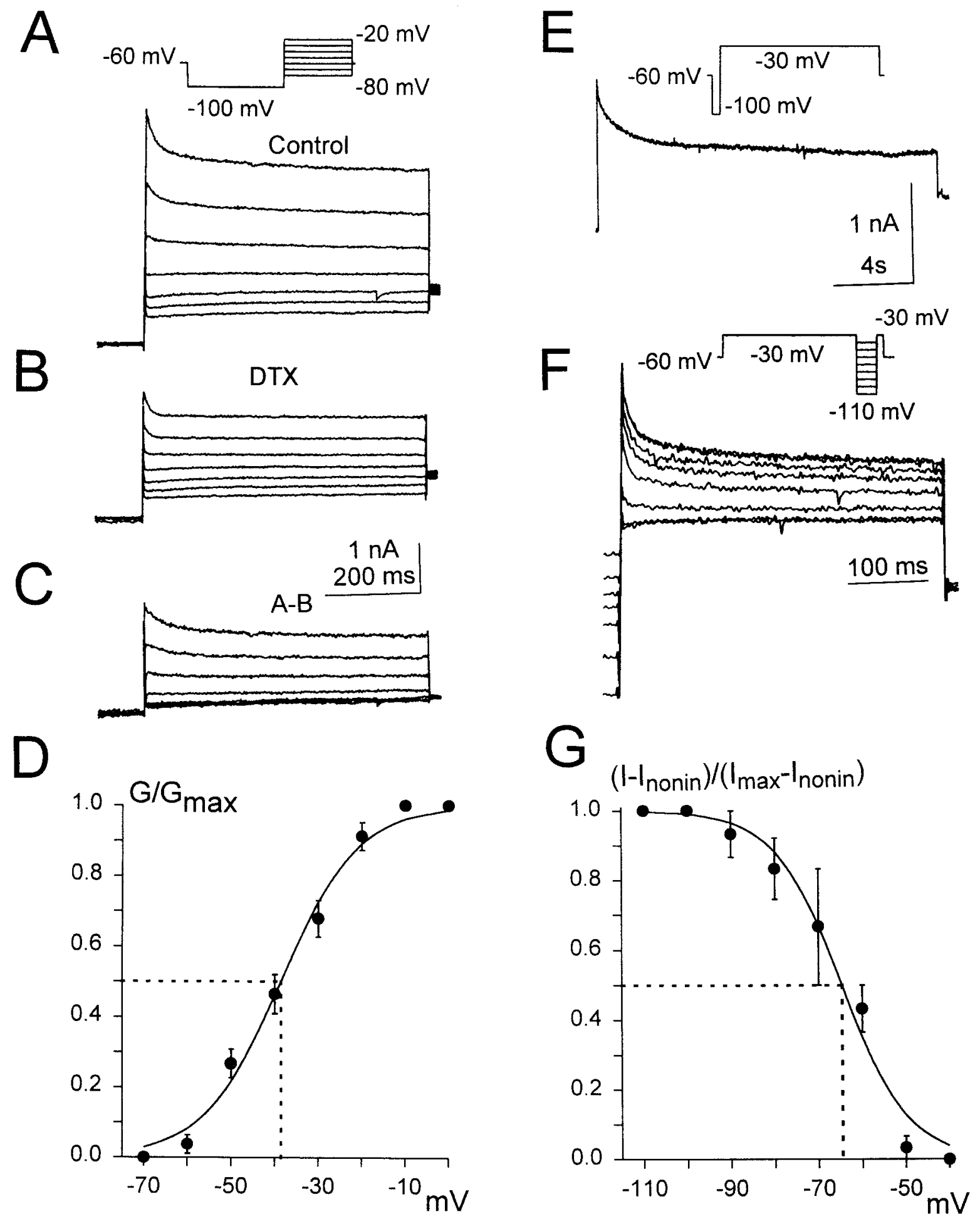

Figure 9. Effect of dendrotoxin on the outward potassium current in accommodating and silent principal cells. Shown is outward potassium current (bottom traces) in $0 \mathrm{Ca}^{2+} \mathrm{ACSF}(A)$ and in $0 \mathrm{Ca}^{2+} \mathrm{ACSF}$ containing $200 \mathrm{~nm} \mathrm{DTX}(B)$. The currents were induced by using $600 \mathrm{msec}$ voltage steps from -80 to $-20 \mathrm{mV}$, with $10 \mathrm{mV}$ increments preceded by an $800 \mathrm{msec}$ prestep to $-100 \mathrm{mV}$ (top traces). $C$, DTX-sensitive current obtained by the subtraction of $B$ from $A$. D. Steady-state activation of averaged and normalized $I_{\mathrm{DS}}$ as a function of membrane potential. The $I_{\mathrm{DS}}$ amplitude necessary for the conductance calculation was measured $300 \mathrm{msec}$ from the onset of the voltage steps. The Boltzmann equation was fit to the data. The dotted line indicates $V_{1 / 2}=-38 \pm 2.1 \mathrm{mV}$. E , The DTX-sensitive current (bottom trace) elicited by 16 sec voltage steps to $-30 \mathrm{mV}$ and preceded by $800 \mathrm{msec}$ presteps to $-100 \mathrm{mV}$. The DTX-sensitive current was obtained by subtracting the current traces obtained in the presence of $200 \mathrm{~nm}$ DTX from control traces recorded in $0 \mathrm{Ca}^{2+}$ ACSF. $F$, To study steady-state inactivation of $I_{\mathrm{DS}}$, we first kept the membrane potential for $8 \mathrm{sec}$ at $-30 \mathrm{mV}$, which was followed by $1200 \mathrm{msec}$ steps from -40 to $-110 \mathrm{mV}$, with $10 \mathrm{mV}$ increments. The current amplitude (bottom traces) was tested by stepping for $400 \mathrm{msec}$ to -30 $\mathrm{mV}$ (top trace). G, Averaged $(n=4)$ and normalized steady-state inactivation of the DTX-sensitive current as a function of membrane potential. The current amplitudes ( $I$ and $I_{\max }$, maximum amplitude) were measured $300 \mathrm{msec}$ from the voltage step onset, and the amplitude of the noninactivating current $\left(I_{\text {nonin }}\right)$ was subtracted. The dotted line indicates $V_{1 / 2}=-66 \pm 3 \mathrm{mV}$. 
analysis of the DTX-sensitive current in silent and accommodating principal cells indicated that there was no significant difference $(p>0.05)$ in the effect of 200 versus $400 \mathrm{~nm}$ concentrations. Moreover, at $-30 \mathrm{mV}, 200$ and $400 \mathrm{~nm}$ DTX blocked $45.2 \pm 3.7 \%$ of the sustained current (measured $300 \mathrm{msec}$ after the start of the step; $n=10$ ) in these cell groups. Although the 100 nм DTX seemed less effective, we were unable to measure reliably the amplitude of the blocked current because of the relatively long latency of this response at the low DTX dose $(n=3)$. At -40 and $-50 \mathrm{mV}$, DTX reduced the sustained currents almost to the level of the leak current (Figs. 9B, 10B), which suggests that the DTX-sensitive current predominates at these potentials. The DTX-sensitive sustained potassium current $\left(I_{\mathrm{DS}}\right)$ activated between -55 and $-65 \mathrm{mV}$ (Fig. $9 D$ ). The kinetics of steady-state activation of $I_{\mathrm{DS}}$ observed in the accommodating and silent principal cells were similar, and the data are summarized together (Fig. 9D). The $V_{1 / 2}$ for activation of the $I_{\mathrm{DS}}$ was $-41.0 \pm 2.1 \mathrm{mV}$, including the liquid junction potential, and $K$ was $8.1 \pm 0.5 \mathrm{mV}$ $(n=10)$. The $I_{\mathrm{DS}}$ was inactivated only partly $(63 \pm 5.3 \%, n=5)$ during a $16 \mathrm{sec}$ voltage steps to $-30 \mathrm{mV}$ (Fig. $9 E$ ). The inactivation rate was fit well with a single exponential curve, and the inactivation time constant was $\tau=1.8 \pm 0.2 \mathrm{sec}(n=5$; fit after the first $300 \mathrm{msec}$ to exclude interference from the fast transient current). To analyze the steady-state inactivation of the $I_{\mathrm{DS}}$, we partly inactivated the current by stepping the membrane potential to $-30 \mathrm{mV}$ for $8 \mathrm{sec}$. After inactivation the membrane potential was stepped from -40 to $-110 \mathrm{mV}$ with $10 \mathrm{mV}$ increments for $1200 \mathrm{msec}$, which was followed by a $400 \mathrm{msec}$ test voltage step to $-30 \mathrm{mV}$ (Fig. 9F). The inactivated sustained current was sensitive to DTX, which established its identity as the $I_{\mathrm{DS}}$ current $(n=$ 3 ). The $V_{1 / 2}$ for inactivation of $I_{\mathrm{DS}}$ was $-69 \pm 3 \mathrm{mV}$, including the liquid junction potential, and $K$ was $4.4 \pm 1.8 \mathrm{mV}$ (Fig. $9 G)(n=$ 4). To avoid an incorrect estimate of $V_{1 / 2}$ caused by the partial inactivation of the current, we fit an alternative inactivation curve, which assumed that the $I_{\mathrm{DS}}$ could achieve full inactivation (Brew and Forsythe, 1995). We used the amplitude of the current after exposure to $200 \mathrm{~nm}$ DTX as a hypothetical measure of the fully inactivated $I_{\mathrm{DS}}$ and fit the curve through this point and the previous inactivation data. Current values were included only after inactivating pulses more negative than $-50 \mathrm{mV}$. From this, the $V_{1 / 2}$ for inactivation was determined to be $-63 \pm 1 \mathrm{mV}$, including the liquid junction potential $(n=3)$. Therefore, it is likely that the true $V_{1 / 2}$ for inactivation is located between -63 and $-69 \mathrm{mV}$, which suggests that $\sim 50 \%$ of this current is available at the resting membrane potential of the principal cells $(-66 \pm 0.6 \mathrm{mV})$. The removal of inactivation from $I_{\mathrm{DS}}$ appears to be a relatively slow process, because $200 \mathrm{msec}$ hyperpolarizing voltage steps to $-100 \mathrm{mV}$ were not sufficient to produce significant recovery from inactivation $(n=3)$. On the other hand, 1200 msec voltage steps seemed sufficient for the full recovery of the $I_{\mathrm{DS}}$ from inactivation. Thus, it is likely that the time constant of inactivation removal is located between 200 and $1200 \mathrm{msec}$.

Besides DTX, $I_{\mathrm{DS}}$ also could be blocked in the presence of 100 $\mu \mathrm{M} 4-\mathrm{AP}$ in the accommodating principal cells $(n=3$; data not shown). In addition, when high concentrations of TEA (10 mM) were applied, both high- and low-threshold potassium currents were blocked ( $n=3$; data not shown). However, in the presence of 200 nм DTX, neither 4-AP $(n=2)$ nor 10 mM TEA $(n=2)$ could reduce further the low-threshold current, indicating that they act on the same type of channel as DTX (data not shown). Exposure of the nonaccommodating principal cells to DTX (200 $\mathrm{nM}, n=6 ; 400 \mathrm{nM}, n=2$ ) blocked only the small, transient portion of the outward potassium current, which almost entirely inactivated during $300 \mathrm{msec}$ (Fig. 10A). This suggests that these principal cells do not possess $I_{\mathrm{DS}}$. Furthermore, after exposure of accommodating or silent principal cells to DTX, the amplitudes of their sustained currents were not significantly different from firing principal cells (Fig. 10B). This further suggests that the differential possession of $I_{\mathrm{DS}}$ is likely to contribute to the distinct firing phenotype expressed in these subpopulations of secondorder vestibular neurons.

To address this question further, in current-clamp experiments we investigated the effect of DTX on the firing pattern of principal cells. The experiments were performed in ACSF containing normal concentrations of calcium, and the recording pipettes contained $1.1 \mathrm{~mm}$ EGTA. Exposure of the accommodating $(n=$ 6) or silent principal cells $(n=4)$ to 200 or 400 nм DTX transformed both classes of cells into neurons firing multiple action potentials on depolarization, with frequencies as high as $100 \mathrm{~Hz}$ in response to $1 \mathrm{nA}$ currents (Fig. $11 A-C$ ). These action potentials were blocked in the presence of $1 \mu \mathrm{M}$ TTX $(n=4)$, indicating that sodium channels were responsible for the trains of spikes on depolarization in these DTX-exposed principal cells. After exposure of the accommodating and silent principal cells to DTX, the threshold for spike initiation was $-50 \pm 3 \mathrm{mV}(n=8)$, which is similar to that of nonaccommodating principal cells $(-48 \pm 2 \mathrm{mV} ; n=8)$. Together, these observations indicate that the differential presence in the principal cells of $I_{\mathrm{DS}}$ is at least partly responsible for the difference in the firing patterns of this special class of developing vestibular neurons in the 16-d-old chick embryo.

Finally, in some neurons, an M-current has been found to be responsible for their accommodation response (Brown and Constanti, 1980). To test for the presence of an M-current, we obtained voltage-clamp recordings from accommodating principal cells exposed to $20 \mu \mathrm{M}$ muscarin, which blocks the M-current in hippocampal slices (Halliwell and Adams, 1982). Applying the same voltage waveform used to test DTX (Fig. 9A), we found that exposure of accommodating principal cells to muscarin (in calcium-free ACSF) did not produce a measurable change in the outward current amplitude $(n=3)$. This finding suggests that the principal cells do not possess an M-current.

\section{DISCUSSION}

The present work is a first attempt to analyze membrane currents and their role in the excitability of embryonic second-order vestibular neurons, using whole-cell voltage-clamp recordings. Previous analyses of membrane currents in this class of vestibular neurons were performed on postnatal animal preparations, using current-clamp recordings (Serafin et al., 1991b; Johnston et al., 1994; Dutia et al., 1995; du Lac, 1996) (for review, see Darlington et al., 1995). Our study confirms a previous report (Peusner and Giaume, 1997) on the presence of two distinct subpopulations of embryonic tangential principal cells that fire either single or multiple action potentials on depolarization. In addition, we have identified a third subpopulation of silent principal cells, which on depolarization do not fire spikes from resting membrane potential.

In principal cells the outward currents could be separated into transient and sustained currents, which may exhibit both highand low-threshold components. Most important, we found that a low-threshold, DTX-sensitive sustained potassium current $\left(I_{\mathrm{DS}}\right)$ is expressed only in the subclasses of silent and accommodating principal cells and that this current is absent in principal cells 

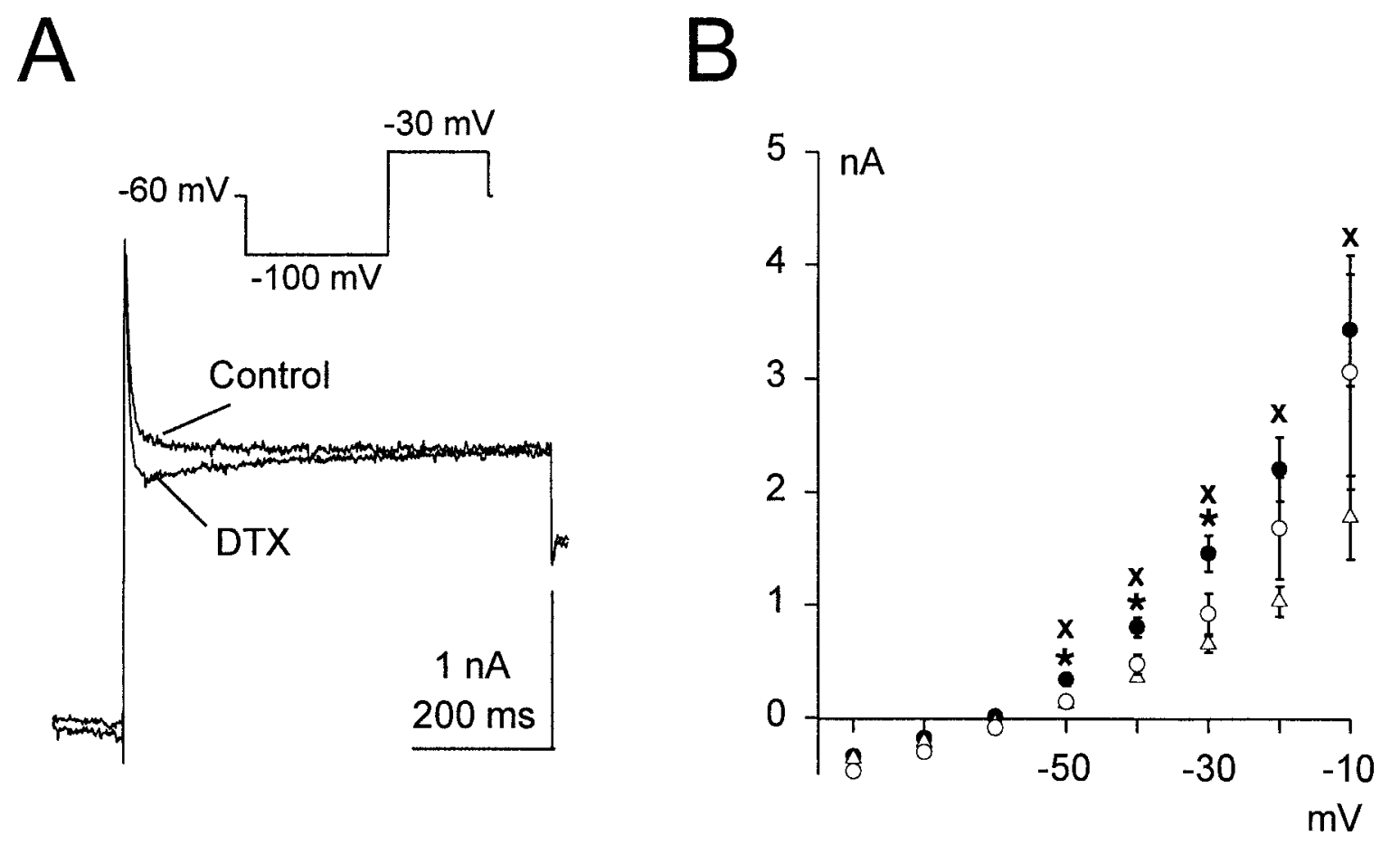

Figure 10. Effect of dendrotoxin on the outward currents in principal cells firing multiple action potentials. $A$, Current traces (bottom traces) induced by stepping the membrane potential to $-30 \mathrm{mV}$ for $600 \mathrm{msec}$, which was preceded by an $800 \mathrm{msec}$ prestep to $-100 \mathrm{mV}$ (top traces) in $0 \mathrm{Ca}{ }^{2+} \mathrm{ACSF}$ (Control) and in $0 \mathrm{Ca}^{2+}$ ACSF containing $200 \mathrm{~nm}$ DTX. B, Current-voltage curve of the sustained currents from (1) averaged, accommodating, and silent cell $(n=12)$ in control, $0 \mathrm{Ca}^{2+} \mathrm{ACSF}(\bullet)$; (2) averaged, accommodating, and silent cell $(n=12)$ in $0 \mathrm{Ca}^{2+} \mathrm{ACSF}^{2}$ containing $200 \mathrm{nM} \mathrm{DTX}(\triangle)$; and (3) firing principal cells in control, $0 \mathrm{Ca}^{2+} \mathrm{ACSF}(\bigcirc)$. An asterisk indicates points of significant difference between the combined data from the silent and accommodating $(\bullet)$ versus nonaccommodating $(O)$ principal cells. $X$ indicates points of significant difference for combined data from the silent and accommodating principal cells before $(\bullet)$ and after $(\triangle)$ exposure to DTX. There was no significant difference in the currents between the silent and accommodating principal cells exposed to DTX $(\triangle)$ and the nonaccommodating cells $(\bigcirc)$. The currents were elicited by using 600 msec voltage steps from -80 to $-10 \mathrm{mV}$, with $10 \mathrm{mV}$ increments, which were preceded by an $800 \mathrm{msec}$ prestep to $-100 \mathrm{mV}$. The sustained current amplitude was measured $300 \mathrm{msec}$ after the onset of the voltage step.

capable of firing multiple spikes on depolarization. We propose that the differential expression of $I_{\mathrm{DS}}$ contributes to the regulation of excitability in the tangential principal cells by controlling their firing rate in response to depolarization.

\section{DTX-sensitive currents in other preparations}

DTX-sensitive currents have been identified in isolated embryonic neuron cultures prepared from rat hippocampus and chick ciliary ganglion (Wu and Barish, 1992; Wisgirda and Dryer, 1993). Like the A-like current in the principal cells, the transient currents in hippocampal neurons have both DTX-sensitive (1 $\mu \mathrm{M})$ and DTXinsensitive components (Wu and Barish, 1992). In neurons from the chick ciliary ganglion, DTX (260-580 nM) suppressed transient and sustained outward currents, which were not tested for their effects on excitability (Wisgirda and Dryer, 1993). The present work is the first report on DTX-sensitive currents in embryonic neurons studied in brain slice preparations. Neurons investigated from brain slices are thought to be more similar to those studied in intact brain, because slices retain considerably more tissue integrity than isolated neuron cell cultures.

In postnatal animal preparations DTX-sensitive currents have been characterized extensively. A low-threshold, DTX-sensitive sustained current, also sensitive to a low concentration of 4-AP, was first described in rat nodose ganglion (Stansfeld et al., 1986) and later in neurons from slice preparations of the medial nucleus of the trapezoid body (Forsythe and Barnes-Davies, 1993; Brew and Forsythe, 1995). In both systems the DTX-sensitive current was found to block repetitive firing on depolarization. In hip- pocampal slices a slowly inactivating 4-AP and DTX-sensitive current was responsible for a delayed spike discharge on depolarization (Halliwell et al., 1986; Storm, 1988). $I_{\text {DS }}$ identified in tangential principal cells was similar in function and steady-state activation kinetics to those DTX-sensitive currents, but it exhibited a partial and slower inactivation. In fact, there was little inactivation during a $500 \mathrm{msec}$ voltage steps of $I_{\mathrm{DS}}$ in principal cells, as observed in dorsal root ganglion neurons (Penner et al., 1986). From studies performed on rat neostriatum it was found that those neurons possess a DTX-sensitive current responsible for a long latency to spike discharge (Nisenbaum et al., 1994). In neurons from the nucleus of the lateral lemniscus (Wen Fu et al., 1996) and the ciliary ganglion (Wisgirda and Dryer, 1993) highthreshold, DTX-sensitive currents were identified, which probably play roles in the repolarization of action potentials (Wen $\mathrm{Fu}$ et al., 1996). Finally, it has been found that potassium channel proteins from the Shaker family, including subunits Kv1.1 and Kv1.2, express high sensitivity to DTX (Grissmer et al., 1994; Hopkins et al., 1994). From this, we suggest that the presence of Kv1.1 and Kv1.2 in embryonic second-order vestibular neurons may be responsible for generating DTX-sensitive currents.

\section{Transient and high-threshold sustained currents in other preparations}

This is the first study reporting a direct identification in secondorder vestibular neurons of a transient A-like current, the presence of which has been proposed from current-clamp recordings on medial vestibular nucleus neurons in postnatal animals (Sera- 
A
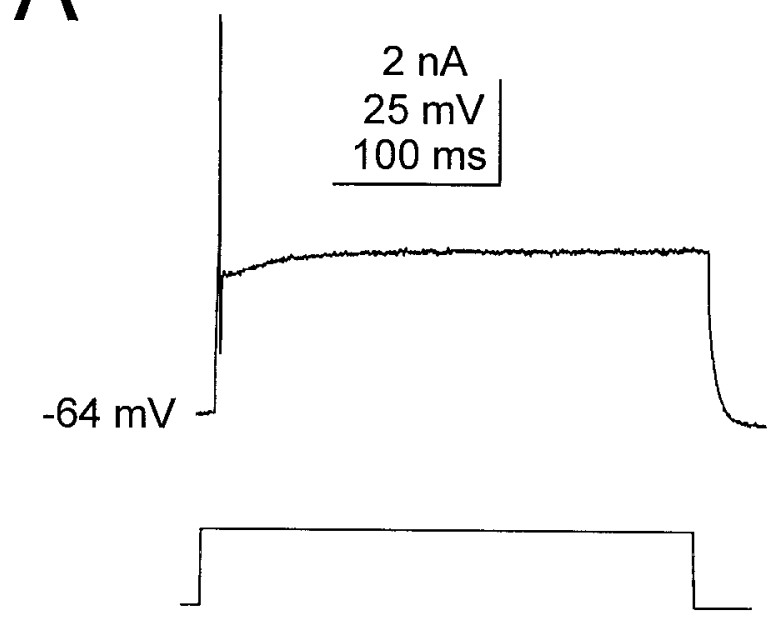

C

60 Number of Spikes in $300 \mathrm{~ms}$
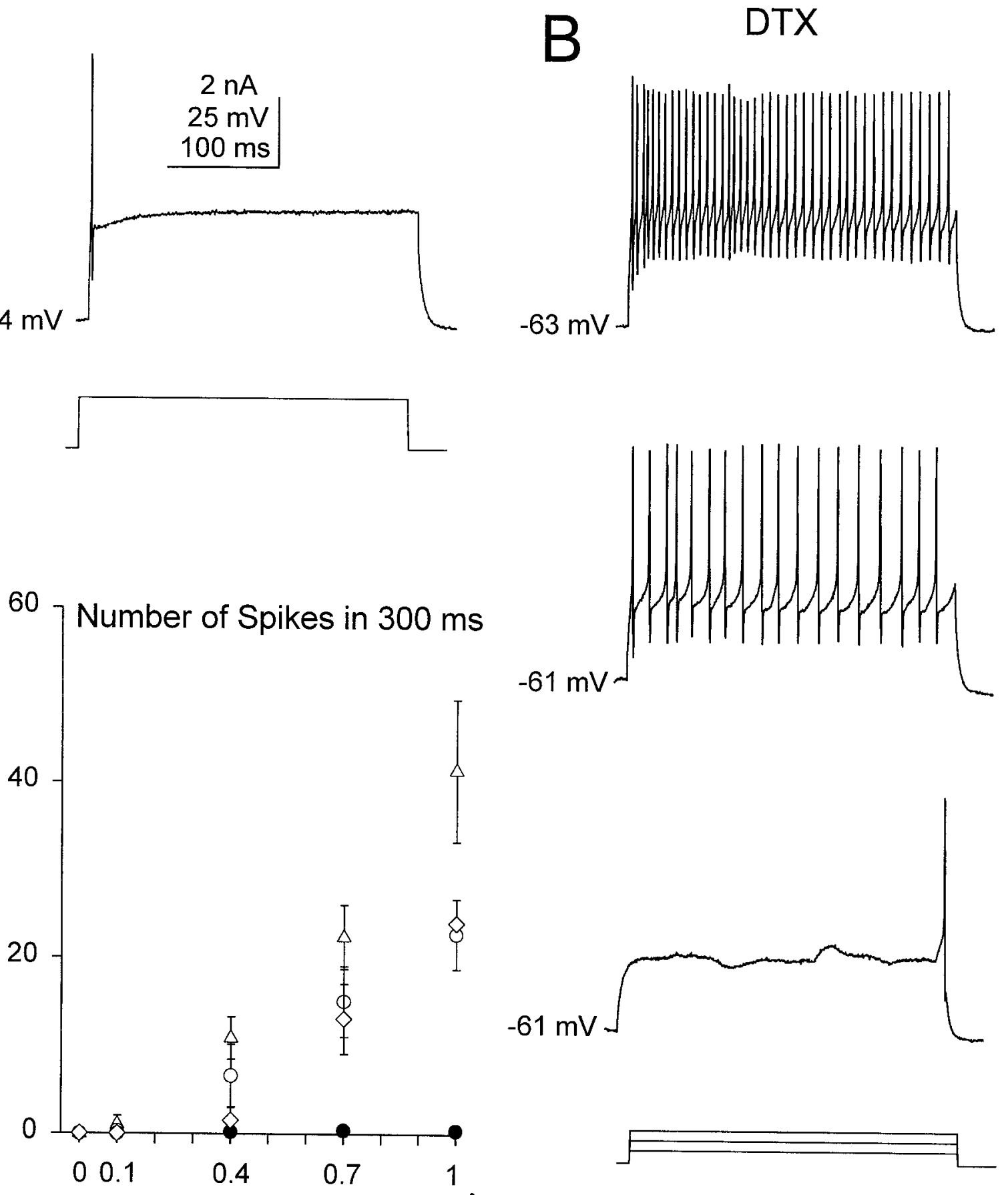

$\mathrm{nA}$

Figure 11. Dendrotoxin transforms accommodating and silent principal cells into neurons capable of firing trains of spikes. Shown are current-clamp recordings of an accommodating principal cell before $(A)$ and after $(B) 200 \mathrm{~nm}$ DTX exposure in normal ACSF. $C$, A plot of the number of spikes in $300 \mathrm{msec}$ versus injected current amplitude for accommodating principal cells $(\bullet, n=5)$, firing principal cells $(\bigcirc, n=5)$, accommodating principal cells after exposure to DTX $(\triangle, n=5)$, and silent principal cells $(\diamond, n=3)$ after exposure to DTX.

fin et al., 1991a,b; Johnston et al., 1994). In tangential principal cells the A-like current possesses at least two components, as described in other embryonic and postnatal systems (Zbicz and Weight, 1985; Storm, 1986; Wu and Barish, 1992) (for review, see Rudy, 1988). The A-like current may be responsible for the fast afterhyperpolarization observed in postnatal vestibular neurons (Serafin et al., 1991a,b; Johnston et al., 1994) and in our preparation. However, we cannot rule out a possible role for sodium and calcium-dependent outward potassium currents in this function. In hippocampal pyramidal and sympathetic ganglion cells, calcium-dependent potassium currents have been shown to be responsible for accommodation (Madison and Nicoll, 1982; Lancaster and Nicoll, 1987; Sacchi et al., 1995). However, calciumdependent and TEA-sensitive sustained potassium currents apparently do not play a significant role in the accommodation of tangential principal cells, perhaps because of their high thresholds 
of activation. We suggest that the TEA-sensitive sustained current, the calcium-dependent potassium currents, and the A-like current may all be involved in the repolarization of the action potential, as already proposed in postnatal neurons of the medial vestibular nucleus (Johnston et al., 1994).

\section{Role of A-like and $I_{\mathrm{Ds}}$ in spike generation}

In the majority of embryonic principal cells the A-like current does not appear to play an important role in setting the action potential threshold or in accommodation, probably because of its relatively positive $V_{1 / 2}$ for activation and its fast inactivation. However, in the silent principal cells the inactivation of the transient current and possibly a small portion of the $I_{\mathrm{DS}}$ by a depolarizing prestep could trigger an action potential. So far, we cannot rule out that the silent principal cells represent a developmentally less mature cell type, which possesses sodium channels that are incapable of producing sufficient inward current to overcome the A-like and $I_{\mathrm{DS}}$ and generate action potentials. In contrast to the A-like current, $I_{\mathrm{DS}}$ exhibits a more negative $V_{1 / 2}$, a steeper slope of activation, and slower inactivation, which allow $I_{\mathrm{DS}}$ to regulate action potential threshold and the firing of multiple spikes. This conclusion is supported further by the finding that the nonaccommodating principal cells do not possess an $I_{\mathrm{DS}}$. Although a contribution from inward currents cannot be excluded, the difference in the expression of $I_{\mathrm{DS}}$ is sufficient to explain the distinction in action potential threshold and in firing pattern between the accommodating and nonaccommodating principal cells. The absence of $I_{\mathrm{DS}}$ from the firing principal cells is not only sufficient but may be necessary for the acquisition of a repetitive firing pattern. Indeed, it has been found that the expression of even small amounts of a low-threshold sustained potassium current could silence rhythmically discharging R15 neurons from mature Aplysia (Zhao et al., 1994). Furthermore, from mathematical neuron models it appears that the presence or absence of the low-threshold sustained potassium current is essential in determining whether neurons exhibit accommodation or repetitive discharge to depolarization (Del Negro and Chandler, 1997).

\section{$I_{\mathrm{Ds}}$ and signal processing in the central vestibular system}

In the 16-d-old chick embryo the firing of multiple spikes on depolarization by the vast majority of principal cells is actively blocked, suggesting that this property could be undesirable for these developing second-order vestibular neurons at this stage. For example, in Xenopus neurons of the neural plate it has been shown that electrical activity plays a critical role in their normal differentiation (Jones and Ribera, 1994). As shown for central auditory neurons (Brew and Forsythe, 1995), $I_{\mathrm{DS}}$ could allow tangential principal cells to follow closely the signals generated by incoming synaptic inputs, especially the large EPSPs generated by the spoon terminals, which could be important for establishing a preliminary connection between the peripheral vestibular receptor and these cells. Further, the simultaneous existence at one age of three subpopulations of principal cells may be important for the function of the vestibular system in the embryo (Rogers, 1996). Finally, the few principal cells firing multiple action potentials on depolarization at E16 resemble the majority of principal cells in young hatchling chickens (Peusner and Giaume, 1997). This suggests that the nonaccommodating principal cells at E16 are more mature developmentally than the other two classes. We have found that the suppression of $I_{\mathrm{DS}}$ is sufficient and possibly necessary for the transformation of accommodating and silent principal cells into the more developmentally mature cells that fire repetitively. This implies that $I_{\mathrm{DS}}$ is regulated developmentally. In fact, our preliminary data from hatchling chickens indicate that principal cells firing multiple spikes on depolarization lack $I_{\mathrm{DS}}$ (Gamkrelidze et al., 1997). In conclusion, our data suggest that the developmental regulation of $I_{\mathrm{DS}}$ is probably essential for the establishment of normal function in the vestibular reflex pathways of the chicken.

\section{REFERENCES}

Bader CR, Bernheim L, Bertrand D (1985) Sodium-activated potassium current in cultured avian neurones. Nature 317:540-542.

Banks MI, Smith PH (1992) Intracellular recordings from neurobiotinlabeled cells in brain slices of the rat medial nucleus of the trapezoid body. J Neurosci 12:2819-2837.

Boyle R, Belton T, McCrea RA (1996) Responses of identified vestibulospinal neurons to voluntary eye and head movements in the squirrel monkey. Ann NY Acad Sci 781:244-263.

Brew M, Forsythe ID (1995) Two voltage-dependent $\mathrm{K}^{+}$conductances with complementary functions in postsynaptic integration at a central auditory synapse. J Neurosci 15:8011-8022.

Brown DA, Constanti A (1980) Intracellular observations on the effects of muscarinic agonists on sympathetic neurones. $\mathrm{Br} \mathrm{J}$ Pharmacol 70:593-608.

Chubb MC, Fuchs AF, Scudder CA (1984) Neuron activity in monkey vestibular nuclei during vertical vestibular stimulation and eye movements. J Neurophysiol 52:724-742.

Cox RG, Peusner KD (1990) Horseradish peroxidase labeling of the efferent and afferent pathways of the avian tangential vestibular nucleus. J Comp Neurol 296:324-341.

Darlington CL, Gallagher JP, Smith PF (1995) In vitro electrophysiological studies of the vestibular nucleus complex. Prog Neurobiol 45:335-346.

Del Negro CA, Chandler SH (1997) Physiological and theoretical analysis of $\mathrm{K}^{+}$currents controlling discharge in neonatal rat mesencephalic trigeminal neurons. J Neurophysiol 77:537-553.

Dryer SE, Fujii JT, Martin AR (1989) $\mathrm{A} \mathrm{Na}^{+}$-activated $\mathrm{K}^{+}$current in cultured brainstem neurones from chicks. J Physiol (Lond) 410:283-296.

du Lac S (1996) Candidate cellular mechanisms of vestibulo-ocular reflex plasticity. Ann NY Acad Sci 781:489-498.

du Lac S, Lisberger SG (1995a) Cellular processing of temporal information in medial vestibular nucleus neurons. J Neurosci 15:8000-8010.

du Lac S, Lisberger SG (1995b) Membrane and firing properties of avian medial vestibular nucleus neurons in vitro. J Comp Physiol [A] 176:641-651.

Dutia MB, Lotto RB, Johnston AR (1995) Post-natal development of tonic activity and membrane excitability in mouse medial vestibular nucleus neurones. Acta Otolaryngol (Stockh) 520:101-104.

Forsythe ID, Barnes-Davies M (1993) The binaural auditory pathway: membrane currents limiting multiple action potential generation in the rat medial nucleus of the trapezoid body. Proc R Soc Lond [Biol] 251:143-150.

Gamkrelidze G, Giaume C, Peusner KD (1997) Role of $\mathrm{K}^{+}$currents in excitability of developing chick vestibular sensory neurons. Soc Neurosci Abstr, 23:751.

Grace AA, Llinás R (1985) Morphological artifacts induced in intracellularly stained neurons by dehydration: circumvention using rapid dimethyl sulfoxide clearing. Neuroscience 16:461-475.

Grissmer S, Nguyen AN, Aiyar J, Hanson DC, Mather RJ, Gutman GA, Karmilowicz MJ, Auperin DD, Chandy KG (1994) Pharmacological characterization of five cloned voltage-gated $\mathrm{K}^{+}$channels, types Kv1.1, $1.2,1.3,1.5$, and 3.1 , stably expressed in mammalian cell lines. Mol Pharmacol 45:1227-1234.

Gross GH, Oppenheim RW (1985) Novel sources of descending input to the spinal cord of the hatchling chick. J Comp Neurol 232:162-179.

Halliwell JV, Adams PR (1982) Voltage-clamp analysis of muscarinic excitation in hippocampal neurons. Brain Res 250:71-92.

Halliwell JV, Othman IB, Pelchen-Matthews A, Dolly OJ (1986) Central action of dendrotoxin: selective reduction of a transient $\mathrm{K}$ conductance in hippocampus and binding to localized acceptors. Proc Natl Acad Sci USA 83:493-497. 
Hamburger V, Hamilton $\mathrm{H}$ (1951) A series of normal stages in the development of the chick embryo. J Morphol 88:49-92.

Hille B (1992) Ionic channels of excitable membranes. Sunderland, MA: Sinauer.

Hopkins WF, Allen ML, Houamed KM, Tempel BL (1994) Properties of voltage-gated $\mathrm{K}^{+}$currents expressed in Xenopus oocytes by mKv1.1, $\mathrm{mKv} 1.2$, and their heteromultimers as revealed by mutagenesis of the dendrotoxin-binding site in mKv1.1. Pflügers Arch 428:382-390.

Jackson MB (1992) Cable analysis with the whole-cell patch clamp. Theory and experiment. Biophys J 61:756-766.

Johnston AR, Macleod NK, Dutia MB (1994) Ionic conductances contributing to spike repolarization and after-potentials in rat medial vestibular nucleus neurons. J Physiol (Lond) 481:61-77.

Jones SM, Ribera AB (1994) Overexpression of a potassium channel gene perturbs neural differentiation. J Neurosci 14:2789-2799.

Kelly PK (1991) The sense of balance. In: Principles of neural science (Kandel ER, Schwartz JH, Jessel TM, ed), pp 500-511. New York: Elsevier.

Klee R, Ficker E, Heinemann U (1995) Comparison of voltagedependent potassium currents in rat pyramidal neurons acutely isolated from hippocampal regions CA1 and CA3. J Neurophysiol 74:1982-1995.

Labandeira-Garcia JL, Guerra-Seijas MJ, Labandeira-Garcia JA, SuarezNunez JM (1989) Afferent connections of the oculomotor nucleus in the chick. J Comp Neurol 282:523-534.

Lancaster B, Nicoll RA (1987) Properties of two calcium-activated hyperpolarizations in rat hippocampal neurones. J Physiol (Lond) 389:187-203.

Lisberger SG, Pavelko TA, Broussard DM (1994) Neuronal basis for motor learning in the vestibuloocular reflex of primates. I. Changes in the responses of brainstem neurons. J Neurophysiol 72:928-953.

Madison DV, Nicoll RA (1982) Noradrenaline blocks accommodation of pyramidal cell discharge in the hippocampus. Nature 299:636-638.

Manis PB, Marx SO (1991) Outward currents in isolated ventral cochlear nucleus neurons. J Neurosci 11:2865-2880.

Mayer LM, Sugiyama K (1988) A modulatory action of divalent cations on transient outward current in cultured rat sensory neurones. J Physiol (Lond) 396:417-433.

Nisenbaum ES, Xu ZC, Wilson CJ (1994) Contribution of a slowly inactivating potassium current to the transition to firing of neostriatal spiny projection neurons. J Neurophysiol 71:1174-1189.

Penner R, Petersen M, Pierau FK, Dreyer F (1986) Dendrotoxin: a selective blocker of a non-inactivating potassium current in guinea-pig dorsal root ganglion neurons. Pflügers Arch 407:365-369.

Peusner KD, Giaume C (1989) Electrophysiological study of the tangential vestibular nucleus of the chick embryo "in vitro." Exp Brain Res 74:80-88.

Peusner KD, Giaume C (1994) The first developing "mixed" synapses between vestibular sensory neurons mediate glutamate chemical transmission. Neuroscience 58:99-113.

Peusner KD, Giaume C (1997) Ontogeny of electrophysiological properties and dendritic pattern in second-order chick vestibular neurons. J Comp Neurol 384:621-633.

Peusner KD, Morest DK (1977) The neuronal architecture and topography of the nucleus vestibularis tangentialis in the late chick embryo. Neuroscience 2:189-207.
Phillips JO, Ling L, Siebold C, Fuchs AF (1996) Behavior of primate vestibulo-ocular reflex neurons and vestibular neurons during head-free gaze shifts. Ann NY Acad Sci 781:276-291.

Ris L, de Waele C, Serafin M, Vidal P, Godaux E (1995) Neuronal activity in the ipsilateral vestibular nucleus following unilateral labyrinthectomy in the alert guinea pig. J Neurophysiol 74:2087-2099.

Rogers LJ (1996) The development of brain and behavior in the chicken. Wallingford, Oxon, UK: Cab.

Rudy B (1988) Diversity and ubiquity of K channels. Neuroscience 25:729-749.

Sacchi O, Rossi ML, Canella R (1995) The slow $\mathrm{Ca}^{2+}$-activated $\mathrm{K}^{+}$ current, $I_{\mathrm{AHP}}$, in the rat sympathetic neurone. J Physiol (Lond) 483:15-27.

Sakmann B, Stuart G (1995) Patch pipette recording from the soma, dendrites, and axon of neurons in brain slices. In: Single-channel recording (Sakmann B, Neher E, eds), pp 199-211. New York: Plenum.

Serafin M, de Waele C, Khateb A, Vidal PP, Muhlethaler M (1991a) Medial vestibular nucleus in the guinea-pig. I. Intrinsic membrane properties in brainstem slices. Exp Brain Res 84:417-425.

Serafin M, de Waele C, Khateb A, Vidal PP, Muhlethaler M (1991b) Medial vestibular nucleus in the guinea-pig. II. Ionic basis of the intrinsic membrane properties in brainstem slices. Exp Brain Res 84:426-433.

Spigelman I, Zhang L, Carlen PL (1992) Patch-clamp study of postnatal development of CA1 neurons in rat hippocampal slices: membrane excitability and $\mathrm{K}^{+}$currents. J Neurophysiol 68:55-69.

Stansfeld CE, Marsh SJ, Halliwell JV, Brown DA (1986) 4-Aminopyridine and dendrotoxin induce repetitive firing in rat visceral sensory neurones by blocking a slowly inactivating outward current. Neurosci Lett 64:299-304.

Storm J (1986) A-current and Ca-dependent transient outward current control the initial repetitive firing in hippocampal neurons. Biophys $\mathrm{J}$ 49:369a.

Storm J (1988) Temporal integration by a slowly inactivating $\mathrm{K}^{+}$current in hippocampal neurons. Nature 336:379-381.

Wen Fu X, Hui Wu S, Brezden BL, Kelly JB (1996) Potassium currents and membrane excitability of neurons in the rat's dorsal nucleus of the lateral lemniscus. J Neurophysiol 76:1121-1132.

Wisgirda ME, Dryer SE (1993) Characteristics of multiple voltageactivated $\mathrm{K}^{+}$currents in acutely dissociated chick ciliary ganglion neurones. J Physiol (Lond) 470:171-189.

Wold JE (1978) The vestibular nuclei in the domestic hen (Gallus domesticus). III. Ascending projections to the mesencephalic motor nuclei. J Comp Neurol 179:393-406.

Wu R, Barish ME (1992) Two pharmacologically and kinetically distinct transient potassium currents in cultured embryonic mouse hippocampal neurons. J Neurosci 12:2235-2246.

Zbicz KL, Weight FF (1985) Transient voltage and calcium-dependent outward currents in hippocampal CA3 pyramidal neurons. J Neurophysiol 53:1038-1058.

Zhao B, Rassendren F, Kaang B, Furukawa Y, Kubo T, Kandel ER (1994) A new class of noninactivating $\mathrm{K}^{+}$channels from Aplysia capable of contributing to the resting potential and firing patterns of neurons. Neuron 13:1205-1213. 